\title{
Risk factors in type 2 diabetes with emphasis on blood pressure, physical activity and serum vitamin $D$
}

\author{
Pär E:son Jennersjö
}

Division of Community Medicine, General Practice

Department of Medical and Health Sciences Linköping University, Sweden

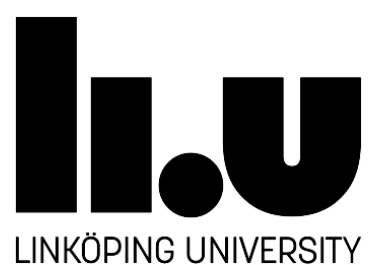

Linköping 2016 
@Pär E:son Jennersjö, 2016

Published article has been reprinted with the permission of the copyright holder.

Printed in Sweden by LiU-Tryck, Linköping, Sweden, 2016

ISBN 978-91-7685-848-6

ISSN 0345-0082 
To my Family 



\section{CONTENTS}

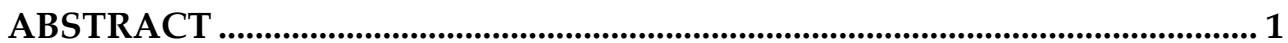

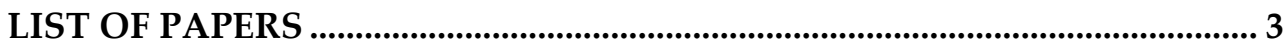

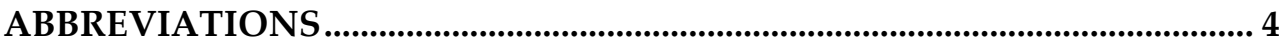

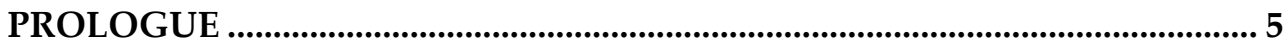

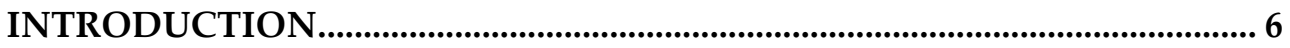

Epidemiology of diabetes mellitus and cardiovascular risk.......................... 6



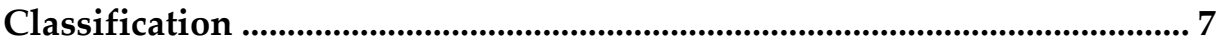

Diagnosis of diabetes mellitus............................................................................... 7

Development of type 2 diabetes ........................................................................... 7

Overweight and obesity........................................................................................ 8

Physical activity ..................................................................................................... 9

Pedometer-determined physical activity.............................................................. 11

Blood pressure ............................................................................................................... 11

Ambulatory blood pressure .................................................................................... 12

Left ventricular hypertrophy ............................................................................ 12

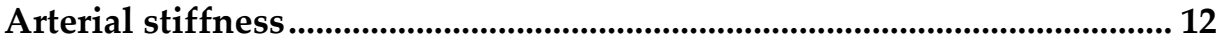

Pulse wave velocity............................................................................................. 13

Vitamin D metabolism................................................................................ 13

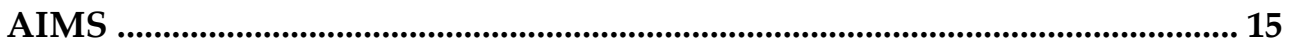

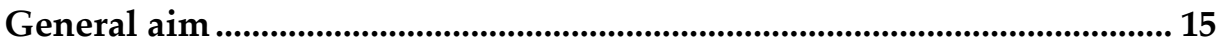

Specific aims .......................................................................................................... 15

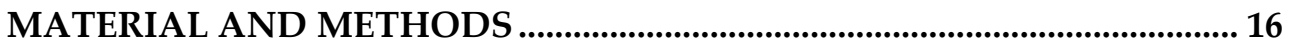






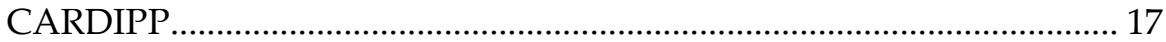

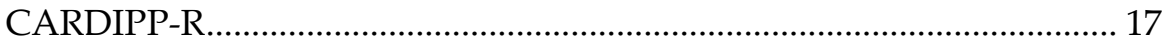

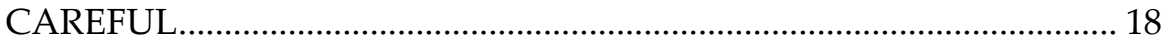

Methods ....................................................................................................... 18

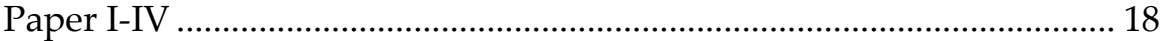

Ambulatory blood pressure ……………............................................. 18

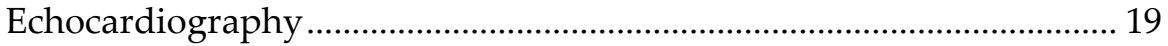

Physical activity and pedometers............................................................. 19

Pulse wave velocity ………….............................................................. 19

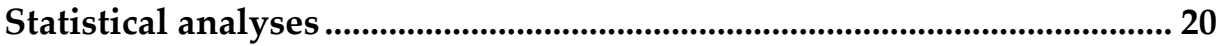

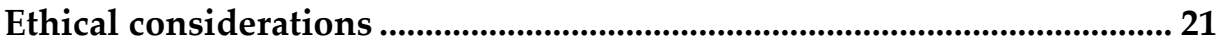

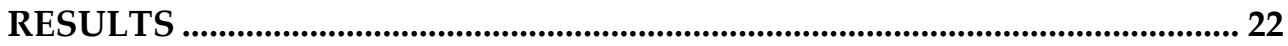

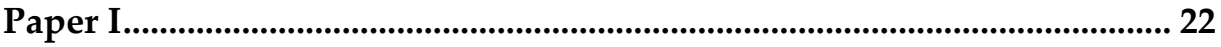

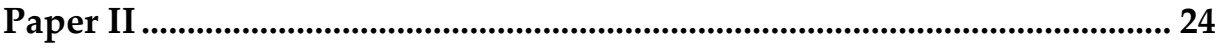

Paper III .............................................................................................................. 29

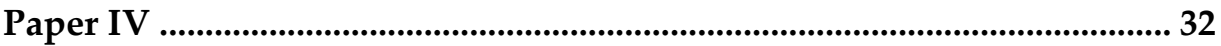

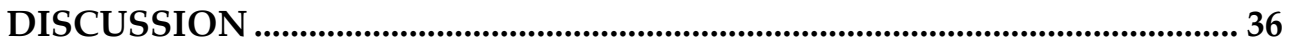

Strengths and limitations ........................................................................ 37

Clinical implications and future research...................................................... 37

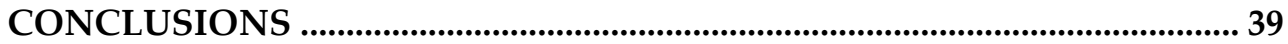

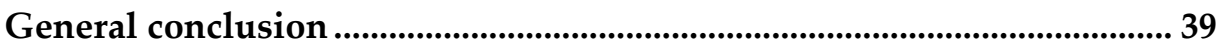

Specific conclusions .................................................................................................. 39

POPULÄRVETENSKAPLIG SAMMANFATTNING ........................................ 40

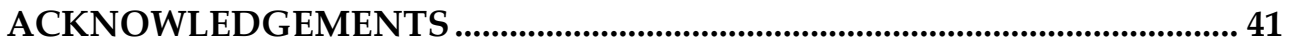

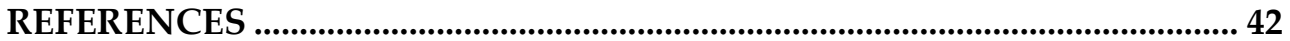




\section{ABSTRACT}

\section{Background}

Type 2 diabetes is a common chronic disease with a two-fold increased risk for cardiovascular morbidity and mortality and has an increasing prevalence worldwide. This thesis is based on a study conducted in primary health care in Östergötland and Jönköping, Sweden. The aim of the thesis was to evaluate new risk markers to identify patients with high risk of developing cardiovascular disease in middle-aged men and women with type 2 diabetes.

\section{Methods}

Data from the cohort study CArdiovascular Risk in type 2 DIabetes - a Prospective study in Primary care (CARDIPP) was used. In paper III data were also used from CARDIPPRevisited where all participants in the CARDIPP study were invited four years after the baseline investigation for a re-investigation. In paper IV data were used from CAREFUL which is a control group of 185 subjects without diabetes.

The investigation included a standard medical history including data on diabetes duration and on-going medication. Anthropometric data were recorded and both office and ambulatory blood pressure were measured. The patients filled out a detailed questionnaire and physical activity was measured by using waist-mounted pedometers. Pedometer-determined physical activity was classified in four groups: Group 1: $<5000$ steps/day ('sedentary'); Group 2: 50007499 steps/day ('low active'); Group 3: 7500-9999 steps/day ('somewhat active'); Group 4: and $\geq 10000$ steps/day ('active'). Blood samples were drawn for routine analyses and also frozen for later analyses. The investigations at the departments of physiology included echocardiography, measurements of the carotid intima-media thickness, applanation tonometry and measurements of sagittal abdominal diameter.

\section{Results}

\section{Paper 1:}

Patients with a non-dipping systolic blood pressure pattern showed higher left ventricular mass index and pulse wave velocity (PWV) compared with patients with $\geq 10 \%$ decline in nocturnal systolic blood pressure. Patients with $<10 \%$ decline in nocturnal systolic blood pressure had higher BMI and sagittal abdominal diameter, lower GFR and higher albumin : creatinine ratio and also higher levels of NT-proBNP than patients with a dipping pattern of the nocturnal blood pressure.

\section{Paper 2:}

The number of steps/day were inversely significantly associated with BMI, waist circumference and sagittal abdominal diameter, levels of CRP, levels of interleukin- 6 and PWV. 


\section{Paper 3:}

At the 4-year follow-up the change in PWV ( $\triangle \mathrm{PWV})$ from baseline was calculated. The group with the lowest steps/day had a significantly higher increase in $\triangle \mathrm{PWV}$ compared with the group with the highest steps/day. The associations between baseline steps/day and $\triangle \mathrm{PWV}$ remained after further adjustment in a multivariate linear regression statistically significant $(\mathrm{p}=0.005) .23 \%$ of the variation in the study could be explained by our model. Every 1000 extra steps at baseline reduced the change in $\triangle \mathrm{PWV}$ by $0.103 \mathrm{~m} / \mathrm{s}$ between baseline and follow-up.

\section{Paper 4:}

Low vitamin D levels were associated with significantly increased risk for premature mortality in men with type 2 diabetes. High levels of parathyroid hormone were associated with significantly increased risk for premature mortality in women with type 2 diabetes. These relationships were still statistically significant also when two other well-established risk markers for mortality, PWV and carotid intima-media thickness, were added to the analyses.

\section{Conclusions}

Ambulatory blood pressure recording can by addressing the issue of diurnal blood pressure variation, explore early cardiovascular organ damage and microvascular complications that goes beyond effects of standardised office blood pressure measurements. Pedometerdetermined physical activity may serve as a surrogate marker for inflammation and subclinical organ damage in patients with type 2 diabetes. There is novel support for the durable vascular protective role of a high level of daily physical activity, which is independent of BMI and systolic blood pressure. The use of pedometers is feasible in clinical practice and provides objective information not only about physical activity but also the future risk for subclinical organ damage in middle-aged people with type 2 diabetes. Our results indicate that low vitamin D levels in men or high parathyroid hormone levels in women give independent prognostic information of an increased risk for total mortality. 


\section{LIST OF PAPERS}

This thesis is based on the following original papers, which are referred to in the text by their Roman numerals:

I. Jennersjö PE, Wijkman M, Wiréhn AB, Länne T, Engvall J, Nystrom FH, Östgren CJ. Circadian blood pressure variation in patients with type 2 diabetes-relationship to macro- and microvascular subclinical organ damage. Prim Care Diabetes 2011;5(3):167-73.

II. Jennersjö P, Ludvigsson J, Länne T, Nystrom FH, Ernerudh J, Östgren CJ. Pedometer-determined physical activity is linked to low systemic inflammation and low arterial stiffness in Type 2 diabetes. Diabet Med 2012;29(9):1119-25.

III. Jennersjö P, Ludvigsson J, Länne T, Nystrom FH, Östgren CJ. Pedometerdetermined physical activity level and change in arterial stiffness in Type 2 diabetes over 4 years. Diabet Med 2015. doi: 10.1111/dme.12873. [Epub ahead of print]

IV. Jennersjö P, Guldbrand H, Björne S, Länne T, Fredrikson M, Lindström T, Wijkman M, Östgren CJ, Nystrom FH. A prospective observational study of allcause mortality in relation to serum 25-OH vitamin D3 and parathyroid hormone levels in patients with type 2 diabetes. Diabetol Metab Syndr 2015;7:53. 


\section{ABBREVIATIONS}

ACR

ADA

BMI

BNP

CARDIPP

CARDIPP-R

CAREFUL

CRP

CV

GFR

IDF

MODY

PTH

PWV

SBP

SPSS

WHO
Albumine : creatinine ratio

American Diabetes Association

Body mass index

Brain natriuretic peptide

Cardiovascular risk factors in patients with type 2 diabetes - a prospective study in primary care

CARDIPP-Revisited

Cardiovascular reference population

C-reactive protein

Coefficient of variation

Glomerular filtration rate

International Diabetes Federation

Maturity onset diabetes of the young

Parathyroid hormone

Aortic pulse wave velocity

Systolic blood pressure

Statistical Package for the Social Sciences; SPSS Inc., Chicago, IL, USA

World Health Organization 


\section{PROLOGUE}

Type 2 diabetes is an epidemically growing chronic disease worldwide and is considered to be one of the most serious threats against health with considerable costs for society and suffering for the individual. The majority of patients with type 2 diabetes are diagnosed and treated in primary health care.

I contributed to the CARDIPP study by the recruitment of patients at two different health care centres. By working with the recruitment, my interest in the field was growing and I therefore wanted to start PhD studies. My research interest in the CARDIPP study, as a general practitioner, is basically because type 2 diabetes is a so common and also a complex disease in primary care. The most common cause of death among patients diagnosed with type 2 diabetes is cardiovascular death which counts for more than half of all deaths. I have therefore found it interesting and important to investigate the relationship between type 2 diabetes and risk factors for cardiovascular diseases with special emphasis on blood pressure and physical activity.

After some years I got interested in vitamin D and therefore I wanted to analyse the levels of vitamin D to explore its associations with mortality in the CARDIPP material. 


\section{INTRODUCTION}

\section{Epidemiology of diabetes mellitus and cardiovascular risk}

Diabetes mellitus is a serious and common chronic disease with an increasing prevalence worldwide. In a recent estimation from International Diabetes Federation (IDF) Diabetes Atlas it was found that 382 million people had diabetes mellitus in 2013 and the number in 2035 was estimated to become 592 million with the majority of the patients coming from China and India (1). The global prevalence in the adult population (20-79 years) is expected to increase from $8.3 \%$ in 2011 to $9.9 \%$ in 2030 (2). In Sweden approximately $3.5 \%$ of the women and $5.1 \%$ of the men are currently diagnosed with diabetes mellitus (3). The incidence of diabetes mellitus in Sweden has been stable for many years (3) and the increasing prevalence might be explained by an aging population with longer lifetime expectancy and also earlier diagnosis of diabetes mellitus. The risk of developing type 2 diabetes is increasing with age (3).

The global burden of diabetes mellitus as a cause of death is substantial. In 2030, diabetes mellitus is likely to be the seventh leading cause of death, in high-income countries the fourth and in low-income countries the ninth leading cause of death (4). The risk of premature death from cardiovascular disease is two times higher among patients with diabetes mellitus compared with individuals without diabetes mellitus (5). The elevated risk for premature death is evident already for newly diagnosed patients compared to individuals without diabetes mellitus (6-9).

\section{Glucose metabolism}

Glucose is an essential nutrient for the human metabolism. The concentration of glucose in plasma is normally 3.9-5.5 mmol/L (10) and is equivalent of an amount of $4 \mathrm{~g}$ glucose (11). Most of the cells in the body can use other nutrients such as fat and protein but the brain is totally dependent on a continuous supply of glucose. To satisfy this need, glucose is stored in the liver as glycogen and released under fasting conditions to sustain glycaemic control and avoid hypoglycaemia. The uptake of glucose in the skeletal muscle and adipose tissue as well the release from glycogen to glucose is regulated by insulin, which reduces the blood glucose level, and glucagon which increases the blood glucose level. These hormones are secreted from the islets of Langerhans in the pancreas. Insulin is produced in the $\beta$-cells and glucagon in the $\alpha$-cells. (12-14). 


\section{Classification}

Diabetes mellitus is a heterogeneous disease with elevated levels of blood glucose. The current classification is based upon recommendations from World Health Organization (WHO) and American Diabetes Association (ADA) where diabetes mellitus is classified into four different groups based on ethiology $(15,16)$.

- Type 1 diabetes accounts for $5-10 \%$ of all diabetes and is caused by an autoimmune $\beta$ cell destruction leading to insulin deficiency.

- Type 2 diabetes is the most common type and represents $85-90 \%$ of all diabetes mellitus. Type 2 diabetes is a mix of insulin resistance and insulin deficiency.

- Other specific types of diabetes: Genetic defects of $\beta$-cell function (MODY), pancreatic diseases (pancreatitis, neoplasia), endocrinopathies (Cushing's syndrome, acromegaly, hyperthyroidism), drug-induced (glucocorticoids, thiazides), infections (mumps), rare genetic disorders (Down's syndrome, Klinefelter's syndrome, Turner's syndrome).

- Gestational diabetes is a temporary disease which occurs during pregnancy. After giving birth the hyperglycaemia is usually reversed. For women with gestational diabetes there is an increased risk of developing type 2 diabetes compared with those who had a normoglycaemic pregnancy. (17).

\section{Diagnosis of diabetes mellitus}

The definition of diabetes mellitus is based on recommendations from the WHO from 1998 $(18,19)$. The diagnosis requires a fasting plasma glucose $\geq 7.0 \mathrm{mmol} / \mathrm{L}$ or a 2 -hour venous glucose of $\geq 11.1 \mathrm{mmol} / \mathrm{L}$ (after an oral glucose load of $75 \mathrm{~g}$ ) alternatively a random venous plasma glucose $\geq 11.1 \mathrm{mmol} / \mathrm{L}$ with symptoms indicating hyperglycaemia. Two consecutive tests are required for diagnosis except when symptoms are present. The diagnosis can also since 2014 in Sweden be based on an HbA1c $\geq 48 \mathrm{mmol} / \mathrm{mol}$ (20). However, the sensitivity by using $\mathrm{HbA} 1 \mathrm{c}$ for diagnosis of diabetes mellitus is considerable lower compared with oral glucose tolerance test (21).

\section{Development of type 2 diabetes}

The onset of type 2 diabetes is usually gradual without early symptoms (22). The pathophysiologic cause of type 2 diabetes is usually a combination of insulin resistance in liver and skeletal muscle and $\beta$-cell failure. The insulin resistance in the skeletal muscle results in decreased glucose uptake and therefore a postprandial hyperglycaemia. Many patients with type 2 diabetes are obese and physically inactive and the obesity, particularly 
visceral adiposity, itself increases the risk for type 2 diabetes predominantly by worsening the insulin resistance. (23). These abnormalities put an excessive stress on the $\beta$-cells which increase insulin production and secretion (24). Eventually, the $\beta$-cells fail to compensate for the insulin resistance and glucose levels rise to overt type 2 diabetes.

There is a strong genetic component for the risk of developing type 2 diabetes. There is an independent association of family history of type 2 diabetes and the risk of future type 2 diabetes further increases with both maternal and paternal diabetes (25-27). The concordance rate of type 2 diabetes in identical twins is $90 \%$ (28).

Insulin resistance is a part of the metabolic syndrome (29-34). According to one frequently cited definition, the metabolic syndrome is characterized by

- elevated waist circumference (caucasian, men $\geq 94 \mathrm{~cm}$, women $\geq 80 \mathrm{~cm}$ )

- elevated triglycerides (or drug treatment) $\geq 1.7 \mathrm{mmol} / \mathrm{L}$

- reduced HDL-cholesterol (or drug treatment) men $<1.0 \mathrm{mmol} / \mathrm{L}$, women $<1.3 \mathrm{mmol} / \mathrm{L}$

- elevated blood pressure (or drug treatment) systolic $\geq 130$ and/or diastolic $\geq 85 \mathrm{~mm} \mathrm{Hg}$

- elevated fasting glucose (or drug treatment) $\geq 5.6 \mathrm{mmol} / \mathrm{L}$

The presence of elevated waist circumference plus 2 of 4 additional criteria defines the metabolic syndrome (29).

Patients with the metabolic syndrome are at high risk of developing type 2 diabetes (35) and of developing cardiovascular disease (36). Patients with type 2 diabetes have an two-fold to four-fold increased morbidity and mortality due to micro- and macrovascular complications. The microvascular complications that are diabetes specific are; retinopathy, nephropathy and neuropathy (37-39). The macrovascular complications are myocardial infarction, stroke and peripheral arterial disease (40).

\section{Overweight and obesity}

There is a global epidemic of obesity that is closely linked to the increasing prevalence of type 2 diabetes. It has been estimated that $23.2 \%$ of the world's population in 2005 was overweight and $9.8 \%$ was obese. The estimated total numbers of overweight adults in 2005 were 937 million and the obese adults were 396 million. By 2030 the prevalence of overweight and obese adults was projected to be $38.1 \%$ overweight and $19.7 \%$ obese individuals respectively, if recent secular trends continue unabated (41).

Development of type 2 diabetes is closely associated with obesity and there is a significant association between obesity, type 2 diabetes and other cardiovascular risk factors (42). Abdominal obesity is the best obesity-related predictor of type 2 diabetes (43).

Visceral fat and intra-abdominal fat is different from subcutaneous fat and excess visceral fat, but not subcutaneous fat, is linked to insulin resistance and the development of type 2 diabetes (44). 
Obesity is closely associated with excess intake of energy and low physical activity. Overweight is defined as a $\mathrm{BMI} \geq 25 \mathrm{~kg} / \mathrm{m}^{2}$ and obesity as a BMI $\geq 30 \mathrm{~kg} / \mathrm{m}^{2}$ (45). Of the larger risks, the attributable burden of high BMI has increased in the past 23 years (46). The definition of obesity using BMI is based on measurements of body weight and height and is therefore independent of the distribution of the fat. In contrast to BMI, waist circumference predicts body intraabdominal fat better and is well correlated to an increased risk for cardiovascular disease (47). Another way to evaluate central obesity is to measure sagittal diameter, i.e. the distance between the back and the highest point of the abdomen measured in a supine position. Recent studies suggest that sagittal abdominal diameter is the best measurement to predict cardiovascular disease (48-50).

\section{Physical activity}

Regular exercise has been recommended as a cornerstone of type 2 diabetes treatment (5153). The importance of regular exercise for health and longevity is evident (54). People who spend higher amounts of time in sedentary behaviours have greater odds of having metabolic syndrome. Reducing sedentary behaviours is potentially important for the prevention of metabolic syndrome (55). Physical activity has been related to postpone development of type 2 diabetes in combination with weight reduction $(56,57)$. Low physical activity is associated with increased prevalence of type 2 diabetes and higher cardiovascular risk in adults $(58,59)$. Despite the well-known benefits of a physically active life-style, patients with type 2 diabetes are generally described as sedentary (60-62).

Inflammation is an important predictor of atherosclerosis and cardiovascular disease $(63,64)$. Physical activity has an anti-inflammatory effect resulting in a decrease in CRP-levels and other inflammatory markers (65-67). Furthermore, physical activity has a positive effect on insulin sensitivity and decreases blood pressure (68-70).

A recent systematic review of 53 studies evaluated 66 programs. Compared with usual care, diet and physical activity promotion programs reduced the incidence of type 2 diabetes with $41 \%$, decreased body weight with $2.2 \%$, decreased fasting blood glucose levels with 0.12 $\mathrm{mmol} / \mathrm{L}$ and improved cardiometabolic risk factors. More intensive programs were more effective compared with programs with less rigorous diet and physical activity promotion (71).

Even non-exercise physical activity has recently been reported to have a great importance for cardiovascular health and longevity (72). 4232 non-diabetic individuals, age 60 years, assessed their non-exercise physical activity and exercise habits at baseline with a selfadministrated questionnaire and their cardiovascular health was established trough physical examinations and laboratory tests. The participants were followed for an average of 12.5 years for the assessment of cardiovascular events and mortality. Individuals reporting a high nonexercise physical activity level, compared with low, had a $27 \%$ lower risk of a first cardiovascular event and $30 \%$ lower all-cause mortality (72). 
There are four large studies among individuals with impaired glucose tolerance which investigate the possibilities to prevent type 2 diabetes by lifestyle interventions: the Chinese Da Qing study (73), the Finnish Diabetes Prevention study (74), the American Diabetes Prevention Project (75) and the Navigator study from 40 countries (76).

In the Chinese Da Qing study, 577 individuals with IGT were randomised to four different groups: a control group, an intervention with diet, an intervention with physical activity or an intervention with both diet and physical activity (73). At follow-up after 6 years the intervention with diet, physical activity and the combined diet-physical activity had reduced the risk of developing diabetes with $31 \%, 46 \%$ and $42 \%$ respectively. The combined dietphysical activity group had in a follow-up after 20 years a reduced type 2 diabetes incidence of $43 \%$ but there were no differences between the groups for cardiovascular events and mortality (77). After 23 years there was a reduced incidence of cardiovascular and all-cause mortality in the intervention group. Cardiovascular mortality was reduced with $41 \%$ and allcause mortality was reduced with $29 \%$ (78).

In the Finnish Prevention study 522 overweight patients with impaired glucose tolerance were randomised to an intervention group or a control group. Each patients in the intervention group received individualised counselling aimed at reducing weight and increasing physical activity. The main follow-up was 3.2 years. The over-all incidence of diabetes mellitus was reduced by $58 \%$ in the intervention group $(74,79)$. At the 10 years follow-up there was no significant decrease in cardiovascular disease in the intensive care group despite maintaining good results concerning glucose control (80).

In the American Diabetes Prevention Project 3234 individuals with elevated fasting plasma glucose or impaired glucose tolerance were randomised to three groups: metformin $850 \mathrm{mg}$ twice daily, physical activity or placebo treatment. Mean follow-up time was 2.8 years. Lifestyle interventions showed decreased conversion rate to type 2 diabetes of $58 \%$ and treatment with metformin showed a decreased conversion rate of $31 \%$. In a follow-up after 10 years there were no significant differences between the groups (81). In the 15-year follow-up the participants who did not develop diabetes mellitus had lower prevalence of microvascular complications than those who did develop diabetes (82).

In the Navigator study 9306 individuals with impaired glucose tolerance had their ambulatory activity assessed by wearing pedometers at baseline and after 12 months. Both baseline ambulatory activity and change in ambulatory activity between baseline and 12 months were significantly and inversely associated with the risk of a cardiovascular event. At baseline, each 2000 steps/day increment in ambulatory activity was associated with a $10 \%$ lower cardiovascular event rate. For change between baseline and after 12 months, each 2000 steps/day increase or decrease in daily ambulatory activity from baseline to 12 months was associated with an additional $8 \%$ lower or higher cardiovascular rate, respectively (76).

In the American Look Ahead study, 5145 overweight or obese patients with type 2 diabetes were randomised to either intensive lifestyle intervention that promoted weight loss through decreased caloric intake and physical activity or a control group. The Look Ahead trial was 
stopped early on the basis of a futility analysis. At the end of the study, with a maximum follow-up of 13.5 years, there was no difference in the number of cardiovascular events between the intervention group and the control group (83). The Look Ahead study did not objectively quantify physical activity and although the Look Ahead study was in intervention study, therefore, the degree to which physical activity was changed as a result of the intervention remains unclear.

\section{Pedometer-determined physical activity}

The use of simple and inexpensive pedometers to quantify ambulatory activity, is a feasible tool for investigating how habitual behaviours are associated with health outcomes $(84,85)$. Wearing a pedometer for three days can provide a sufficient estimate of physical activity in adults (86). Compared with accelerometers, pedometers are less expensive and more practical for both research and clinical applications (87). In addition to being used to quantify habitual walking activity, pedometers may be useful motivational tools to encourage patients with type 2 diabetes to increase their physical activity $(87,88)$. A value of 10000 steps/day or more appears to be a reasonable estimate of daily activity for apparently healthy adults (89-91) and there is growing evidence that 10000 steps/day or more is an amount of physical activity that is associated with indicators for good health. However, it has recently been suggested that 7000-8000 steps/day is a more direct translation of public health guidelines than 10000 steps/day (92). But only the cut-off level of $>10000$ steps/day has shown to be beneficial to patients with type 2 diabetes in terms of reducing weight and improving insulin sensitivity in a clinical trial (87). Individuals who accumulate at least this amount of activity have less body fat (93) and lower blood pressure (94) than their less active counterparts.

In a recent population based cohort study in Tasmania, Australia, 592 middle-aged adults had their physical activity measured with pedometers at baseline and follow-up after five years. A higher daily steps/day at five year follow-up than at baseline was associated with better insulin sensitivity and the effect seemed to be largely mediated through lower adiposity (95).

\section{Blood pressure}

When diabetes mellitus is combined with hypertension the cardiovascular risk increases additionally $(96,97)$. In American and European guidelines on hypertension management the recommended blood pressure goal for treatment is less than $140 / 90 \mathrm{mmHg}(98,99)$. A very recent large clinical trial has shown that the lower the blood pressure was, the better the outcome (100). 


\section{Ambulatory blood pressure}

Office blood pressure is routinely used but ambulatory blood pressure measurement is better correlated with micro- and macrovascular complications (101-104). A single office blood pressure measurement may underestimate or overestimate the strength of the association between the blood pressure level and the risk for cardiovascular disease. One way to overcome this problem is to use an automated device which measures the blood pressure repeatedly over 24 hours, since the larger number of measurements minimises the influence of individual random measurement errors. The blood pressure altering influence of the encounter with the person measuring the blood pressure is also eliminated. Several studies have shown that, compared with office blood pressure levels, ambulatory blood pressure levels are more closely associated with the risk for cardiovascular disease $(105,106)$.

Ambulatory blood pressure monitoring can also measure the nocturnal blood pressure. In the general population a reduced difference between night and day-time blood pressure, which is denoted as non-dipping, is associated with left ventricular hypertrophy (107) and left ventricular dilatation (108), increased arterial stiffness (109) increased carotid intima media thickness (110) and elevated risk of cardiovascular disease and premature mortality (111-113) regardless of the mean value of arterial blood pressure during 24 hours (114).

\section{Left ventricular hypertrophy}

Increased left ventricular mass is a compensatory response for the heart to increased afterload and left ventricular mass increases with increasing blood pressure. The golden standard in routine practice for identification of left ventricular hypertrophy is echocardiography. Left ventricular hypertrophy is associated with an increased risk for cardiovascular disease, cardiovascular mortality and all-cause mortality in patients with hypertension $(115,116)$. The presence of left ventricular hypertrophy in hypertensive populations is likely to exclude patients with white-coat hypertension who are less likely to develop signs of target organ damage. Antihypertensive treatment may lead to left ventricular hypertrophy regression and treatment induced regression of left ventricular hypertrophy is associated with reduced risk for cardiovascular disease (117).

\section{Arterial stiffness}

Age and blood pressure are the two most important risk factors for arterial stiffness (118, 119). The stability of the vascular wall is depending on the balance between two prominent proteins, collagen an elastin. The stiffening process involves structural and functional rearrangements of the elastic material in the arterial wall. Hypertension, type 2 diabetes and inflammation lead to a shift towards more collagen and less elastin. The vessel therefore becomes less elastic. Hyperglycaemia and hyperinsulinemia induce the renin-angiotensin- 
aldosteron system and up-regulates the expression of angiotensin-I receptor that promotes the fibrosis in the vessel wall (120).

In a person with increased arterial stiffness, both the forward travelling pulse wave and the sum of its reflected, backwards travelling pulse waves will travel at increased velocity, and the accumulated reflected pulse wave will reach the central aorta earlier than in a person with lower arterial stiffness. This means that in a person with markedly increased arterial stiffness, the reflected pulse wave will return to the central aorta earlier, prior to the closure of the aortic valve, i.e. during systole, thus augmenting afterload by increasing the central systolic blood pressure and widening the central pulse pressure. This is in contrast to what happens in a person with lower arterial stiffness, in which the reflected pulse wave will reach the central aorta after the closure of the aortic valve, i.e. during diastole, thus instead augmenting the coronary perfusion by increasing the central diastolic blood pressure.

\section{Pulse wave velocity}

Markers of arterial stiffness are useful tools to identify early atherosclerosis and the risk for adverse clinical outcomes in individuals with a modest risk factor profile. Assessing arterial stiffness may facilitate cardiovascular risk stratification beyond traditional risk scores (121). Aortic pulse wave velocity (PWV) is regarded as the reference method for assessment of arterial stiffness and a known risk factor for premature cardiovascular morbidity and mortality (122). High PWV is a strong independent risk factor for cardiovascular mortality, fatal and non-fatal coronary events and fatal strokes in people with hypertension (123-125), end-stage renal disease (126), type 2 diabetes $(127,128)$, and in older adults $(129,130)$ and in the general population (131).

\section{Vitamin D metabolism}

Vitamin D plays a classical hormonal role in skeletal health by regulating calcium and phosphorus metabolism. Vitamin D metabolites also have physiological functions in nonskeletal tissues. The active metabolite of vitamin D binds to the vitamin D receptor that regulates numerous genes involved in fundamental processes of potential relevance to cardiovascular disease. Vitamin D receptors have been found in all the major cardiovascular cell types including cardiomyocytes, arterial wall cells, and immune cells. Experimental studies have established a role for vitamin D metabolites in pathways that are integral to cardiovascular function and disease, including inflammation, thrombosis, and the reninangiotensin system (132).

Vitamin D is stored in adipose tissue and liver in an inactive form. Serum levels of vitamin D are negatively related to adiposity $(133,134)$. Prospective observational studies have shown inverse associations between serum vitamin D and future risk of hyperglycaemia, insulin resistance and diabetes (135-140). Low levels of serum vitamin $\mathrm{D}$ (25-OH vitamin $\mathrm{D}_{3}$ ) have 
been linked with an increased for mortality in different non-diabetic populations $(141,142)$. In experimental studies vitamin $\mathrm{D}$ has been shown to reduce activity in the renin angiotensin system (143). Vitamin D has also been inhibited by action of vitamin D $(144,145)$ suggesting causality between low levels of vitamin D and increased prevalence of cardiovascular disease (146). On the other hand there are two large studies among individuals with high levels of vitamin D where the finding is an increased mortality rate $(147,148)$. Deficiency of vitamin D leads to increased levels of parathyroid hormone (PTH) levels which allow release of calcium that is stored in bone tissue. High levels of PTH have been linked with increased arterial calcification in a population-based study in Sweden $(149,150)$ and it is well known that secondary hyperparathyroidism is an indicator of poor outcome in renal diseases in which activation of vitamin D is deficient (151). Recently it was shown that patients with type 2 diabetes and low vitamin D levels had an increased risk for all-cause mortality in a study with median follow-up of 15 years $(152,153)$.

Clinical trials exploring the effects of treatment with vitamin D in non-diabetic patients on blood pressure and vascular function have shown benefits in some $(154,155)$, but not all studies $(156,157)$. A recent large meta-analysis did not find a reduced risk for cardiovascular disease or mortality after administration of vitamin D (158). However, the studies were not specially targeted for evaluation of mortality, nor were they confined to patients with type 2 diabetes. 


\section{AIMS}

\section{General aim}

To cross-sectionally and prospectively analyse the associations between new aspects of cardiovascular risk factors as blood pressure, pedometer-determined physical activity and vitamin $\mathrm{D}$ with subclinical cardiovascular organ damage and mortality in type 2 diabetes.

\section{Specific aims}

- To explore the association between nocturnal blood pressure dipper status versus arterial stiffness, left ventricular mass and microalbinuria in patients with type 2 diabetes, respectively.

- To explore the association between pedometer-determined physical activity versus inflammatory markers and arterial stiffness in type 2 diabetes.

- To explore the association between pedometer-determined physical activity at baseline and the subsequent development of arterial stiffness after 4 years.

- To assess if levels of serum vitamin D predict the risk for total mortality in type 2 diabetes. 


\section{MATERIAL AND METHODS}

The studies in this $\mathrm{PhD}$ thesis are based on data from participants in three data collections in primary care in the counties of Östergötland and Jönköping, Sweden, Figure 1.

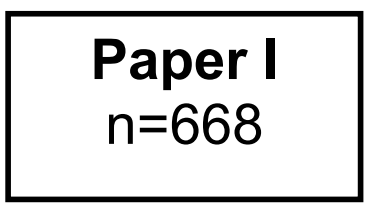

\section{Paper II $\mathrm{n}=327$}

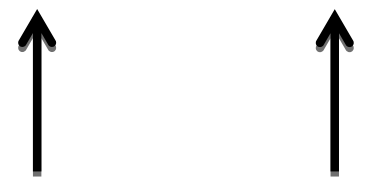

CAREFUL (no diabetes) $\mathrm{n}=185$
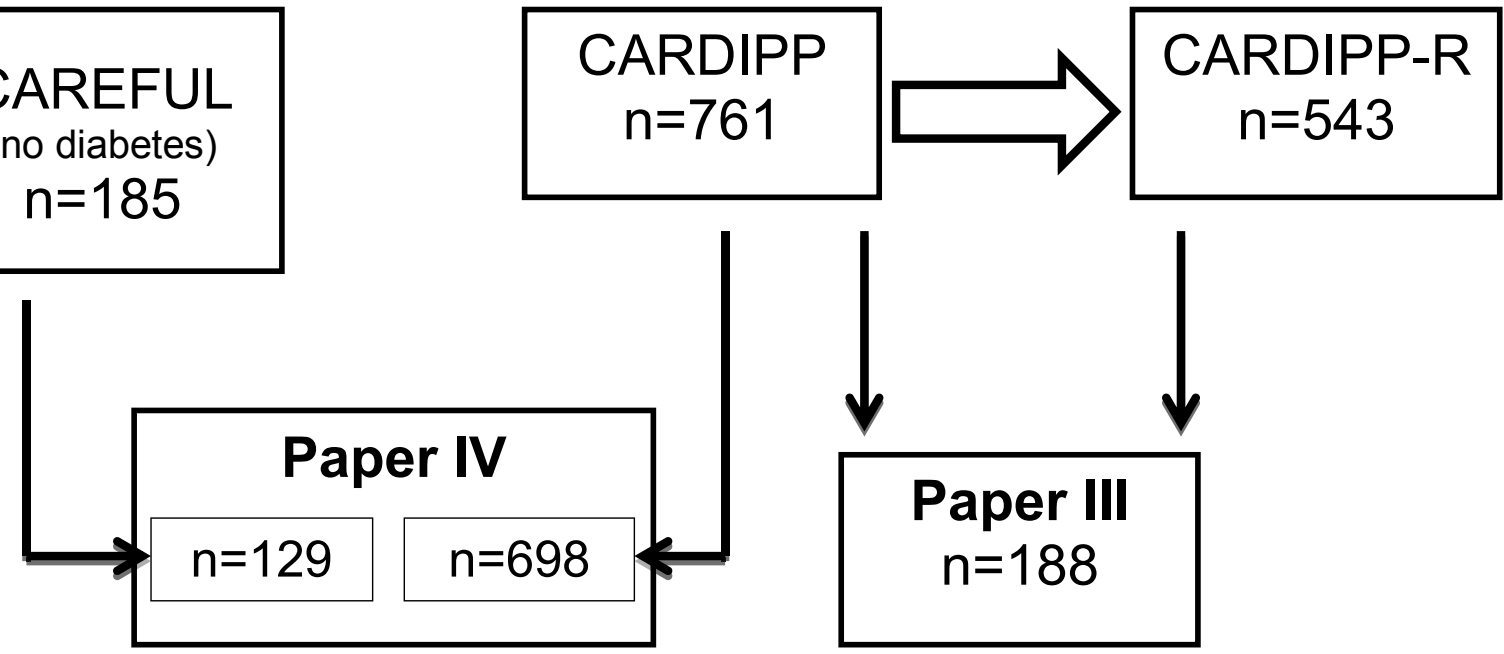

Figure 1: The four papers in this thesis according to the different study populations. 


\section{Study populations}

\section{CARDIPP}

CArdiovascular Risk factors in patients with type 2 DIabetes - a Prospective study in Primary care (CARDIPP), was launched in November 2005 and by the end of 2008, 761 patients with type 2 diabetes were consecutively recruited from 25 different primary care health centres in the counties of Östergötland and Jönköping, Sweden. CARDIPP comprises data on an extended annual follow-up on patients aged 55-66 years.

The centres were located in different demographic areas, both rural and urban, and differed in size. However, the model of treatment and care of type 2 diabetes was organized similarly and all centres adhered to the same national guidelines of diabetes care. The annual follow-ups were performed at the primary care health centres and were conducted by nurses especially dedicated to treatment of diabetes mellitus.

The investigation included a standard medical history including data on diabetes duration and on-going medication. The patients filled out a detailed questionnaire for evaluation of selfreported lifestyle factors and exercise habits. The physical activity was in 327 individuals measured by using waist-mounted pedometers. The nurses measured height, weight and also blood pressure, both conventional office blood pressure and ambulatory blood pressure. At the visit to the nurse the patients were booked for examinations at the Department of Physiology either at Linköping University Hospital or at the Ryhov County Hospital in Jönköping. Blood samples were drawn after 10 hours over-night fast for routine lab analyses and were also frozen for later analyses.

The investigations at the departments of physiology included echocardiography for determining the left ventricular mass, measurements of the intima-media thickness of the common carotid artery, applanation tonometry over the carotid, femoral and radial arteries for determining the pulse wave velocity and also measurement of the sagittal abdominal diameter.

\section{CARDIPP-R}

CARDIPP-Revisited (CARDIPP-R) comprised a re-investigation of the cohort four years after the completion of the baseline exanimation. In CARDIPP-R all patients from the baseline study were invited to the re-investigation that was performed between 2010 and 2013. Of the 761 patients included in the baseline study, 543 patients $(71 \%)$ participated in the re-investigation. The same study protocol for echocardiography and tonometry as used in the baseline investigation was used at the re-investigation. The re-investigations were performed at the two departments of physiology and routine laboratory tests were performed at the local primary health care centres. 


\section{CAREFUL}

The CArdiovascular REFerence popULation (CAREFUL) was a data collection of agematched individuals that served as non-diabetic controls. The 185 study participants in CAREFUL has been randomly selected from a population registry of individuals aged 50-70 years who resided within the catchment area of Linköping University Hospital. Individuals with previously known or newly discovered diabetes mellitus or a family history or known diagnosis of aortic aneurysm were not eligible for participation in CAREFUL. The individuals in CAREFUL were not followed prospectively but underwent similar baseline examinations as the patients who participated in CARDIPP except from the use of pedometers.

\section{Methods}

\section{Paper I-IV}

Diabetes duration was defined as the time from the diagnosis of type 2 diabetes until baseline examination. Weight and height were measured with the patients wearing light indoor clothing without shoes. Blood specimens were drawn in the morning after 10 hours overnight fast.

The urinary albumin excretion rate was measured using the albumine:creatinine ratio (ACR) in one single morning spot urine samples. Urine concentration of creatinine was measured by an enzymatic method. Microalbuminuria was defined as an ACR $\geq 3.0 \mathrm{mg} / \mathrm{mmol}$. Estimated glomerular filtration rate (GFR) was calculated from plasma cystatin C-levels by the formula $\mathrm{y}=79.901$ (cystatin C-level) $^{-1.4389}$ (159).

\section{Ambulatory blood pressure}

Specially trained nurses at each primary health care centre were responsible for the measurement of office blood pressure and the 24-h ambulatory blood pressure recordings. Office blood pressure was the average of three seated measurements taken one minute apart after five minutes rest. Ambulatory blood pressure was measured with Spacelab 90217, a common device in Swedish health care. It was set to measure the blood pressure at 20-minute intervals for 24 hours. The 24-h blood pressure mean values for day and night blood pressure were based on individual self-reported data on time spent in bed. Night time was defined as the period between the time when the patient reported going to bed and the time when the patient reported getting out of bed the following morning. No manual editing of the monitoring readings was performed. Only patients with data on both day-time and night-time blood pressure recordings and with $\geq 70 \%$ successful ambulatory blood pressure measurements were included. The nocturnal systolic blood pressure (SBP) dipping in percent 
was calculated as $100 \mathrm{x}$ (mean day-time SBP - mean night-time SBP)/(mean day-time SBP). Non-dippers were defined as a $<10 \%$ nocturnal decrease in systolic blood pressure.

\section{Echocardiography}

Echocardiography was performed with the patient in the left semi-lateral position and left ventricular mass was determined according to the method described by Devereux (160). The measurements were done in M-mode. The Penn convention was then used for the calculation of left ventricular mass.

\section{Physical activity and pedometers}

The participants filled out a detailed questionnaire for evaluation of self-reported life style factors and exercise habits. The question about physical exercise is currently used in the National Survey of Public Health, Health on Equal Terms, that has been conducted yearly since 2004 by the Swedish National Institute for Public Health (161).

The physical activity was measured using waist-mounted pedometers, Yamax SW200/KeepWalking LS2000 (162) for three consecutive days and the number of steps/day were then calculated. The pedometers were sealed in such a way that the participants were unable to see or manipulate the pedometer counts during the observation period. All participants were asked to wear the pedometers for three consecutive days but also to register on a form how many days they used the pedometer and to return the form to the study nurse after completion. Most participants wore the pedometer for three days and the output was then divided by three or the actual number of days. Two participants wore the pedometer for two days, three participants for four days, one participant for six days, and one participant had the pedometer for seven days and the numbers of steps were thus consequently divided accordingly by the actual number of days. Based on currently available recommendations (87, 89-91), we classified the pedometer-determined physical activity in four groups:

Group 1: $<5000$ steps/day ('sedentary');

Group 2: 5000-7499 steps/day ('low active');

Group 3: 7500-9999 steps/day ('somewhat active');

Group 4: and $\geq 10000$ steps/day ('active').

\section{Pulse wave velocity}

Aortic pulse wave velocity (PWV) was measured with applanation tonometry over the carotid and femoral arteries. The aortic pulse wave transit times were measured by electrocardiogram-guided readings of the femoral arterial pulse waves, using the carotid arterial pulse wave as the reference site. The surface distances were estimated from the 
suprasternal notch to the carotid and femoral measurements sites, respectively. PWV was calculated by dividing the surface distance with the pulse wave transit time yielding the PWV in $\mathrm{m} / \mathrm{s}$.

Three biomedical scientists performed all vascular measurements. The intra-individual coefficient of variation (CV) for PWV was $8.1 \%$. The change in PWV ( $\triangle \mathrm{PWV}$ ) was calculated as the difference between the recording at baseline and the 4-year follow-up investigation.

\section{Statistical analyses}

In paper I differences in continuous variables, between the dipping and non-dipping category, were analysed with Student's t-test. When analysing the nocturnal systolic blood pressure dipping in percent of daytime systolic blood pressure as a continuous and dependent variable in a multiple linear regression analysis adjusted for office systolic blood pressure, the increase of one unit for each of the variables conferred a change in dipping in percent units expressed as the as the regression coefficient $(\beta)$ with $95 \%$ confidence intervals (CI).

Variables with skewed distributions in paper II, IL-6, and hs-CRP, were log transformed in all analyses. In analyses between continuous variables multiple linear regression analyse were used and Pearson correlation coefficients were calculated, using bivariate correlation analysis. Group differences between categorical variables and continuous variables were analysed with ANOVA and Student's t-test, respectively.

The Kolmogorov-Smirnov test indicated an approximatively normal distribution in PWV at baseline and in change of PWV from baseline to follow-up. Multiple linear regression was therefore carried out to examine the association between changes in PWV from baseline to follow-up in paper III. To adjust this association for possible confounding factors the regression analyses were adjusted for sex, age, diabetes duration, HbA1c, BMI, systolic blood pressure, PWV at baseline, beta-blockers, statins, unemployment, smoking and diabetic treatment. Possible differences in continuous variables, e.g. age, blood pressure, between the four physical activity groups were tested with ANOVA and Student's t-test. The Pearson correlation coefficient was used to measure the strength of the linear association between baseline steps/day and PWV.

In the survival analyses in paper IV, Cox regression proportional hazard model was used to explore the association between vitamin $\mathrm{D}$, parathyroid hormone and all-cause mortality. The statistical significance of between-group differences were tested with unpaired Student's ttests for continuous variables, and with the Chi-Square test for dichotomous variables. Estimates of adjusted between-group differences were obtained by multiple regression analysis. To assess strengths of correlations between continuous variables, Pearson correlation coefficients were calculated. 
All tests were two-sided and statistical significance was assumed when $\mathrm{p}<0.05$. SPSS for Windows 18.0-22.0 was used for statistical analysis.

\section{Ethical considerations}

All studies complied with the Declaration of Helsinki. Written informed consent was obtained from each participant at each participating site. The studies were approved by the Regional Ethical Review Board at Linköping University, Sweden, nr 26-05 (CARDIPP), nr 26-05, T8006 (CAREFUL) and nr 26-05, 2013/194-32 (mortality/hospital discharge diagnosis). All participants could withdraw at any point if they chose to. All data were unidentified, presented on a group level and specific participants could not be singled out or identified. 


\section{RESULTS}

\section{Paper I}

The main finding was that patients with a non-dipping systolic blood pressure pattern showed higher left ventricular mass index and PWV compared with patients with $\geq 10 \%$ decline in nocturnal systolic blood pressure. Patients with $<10 \%$ decline in nocturnal systolic blood pressure had higher BMI and sagittal abdominal diameter, lower GFR and higher ACR and also higher levels of NT-proBNP than patients with $\mathrm{a} \geq 10 \%$ decline in the nocturnal systolic blood pressure. There were no difference between the dipping and non-dipping groups with respect to age, diabetes duration, HbA1c and CRP. The results are shown in Table 1 and Table 2.

Table 1 Differences in baseline characteristics according to nocturnal systolic blood pressure dipping status

\begin{tabular}{|l|c|c|c}
\hline & $\begin{array}{c}\geq 10 \% \text { dipping } \\
\mathrm{n}=433 \\
\mathrm{~m}(\mathrm{SD})\end{array}$ & $\begin{array}{c}<10 \% \text { dipping } \\
\mathrm{n}=230 \\
\mathrm{~m}(\mathrm{SD})\end{array}$ & $\mathrm{p}$ \\
\hline Age (years) & $60.6(3.1)$ & $60.9(3.0)$ & $\mathrm{ns}$ \\
\hline Diabetes duration (years) & $7.1(6.4)$ & $7.8(5.8)$ & $\mathrm{ns}$ \\
\hline BMI $\left(\mathrm{kg} / \mathrm{m}^{2}\right)$ & $29.9(4.6)$ & $30.7(4.7)$ & 0.036 \\
\hline Waist circumference $(\mathrm{cm})$ & $103.9(11.7)$ & $105.7(11.9)$ & $\mathrm{ns}$ \\
\hline Sagittal abdominal diameter $(\mathrm{cm})$ & $25.3(3.7)$ & $26.1(3.8)$ & 0.013 \\
\hline Office Systolic blood pressure $(\mathrm{mm} \mathrm{Hg})$ & $136.0(16.2)$ & $139.0(16.4)$ & 0.024 \\
\hline Office Diastolic blood pressure $(\mathrm{mm} \mathrm{Hg})$ & $79.7(9.7)$ & $80.8(10.7)$ & $\mathrm{ns}$ \\
\hline Aortic pulse wave velocity $(\mathrm{m} / \mathrm{s})$ & $10.1(2.1)$ & $10.8(2.1)$ & $<0.001$ \\
\hline Left ventricular mass index $\left(\mathrm{g} / \mathrm{m}^{2}\right)$ & $119.3(29.4)$ & $125.0(31.8)$ & 0.038 \\
\hline HbA1c $(\%)$ & $6.0(1.1)$ & $6.2(1.1)$ & $\mathrm{ns}$ \\
\hline GFR $\left(\mathrm{mL}\right.$ min $\left.{ }^{-1} / 1.73 \mathrm{~m}^{2}\right)$ & $100.2(25.7)$ & $88.6(20.7)$ & 0.001 \\
\hline ACR $\left(\mathrm{mg} / \mathrm{mmol}^{2}\right)$ & $2.0(9.7)$ & $5.0(17.1)$ & 0.004 \\
\hline NT-proBNP $(\mathrm{ng} / \mathrm{L})$ & $92.3(145.3)$ & $130.6(206.3)$ & 0.010 \\
\hline CRP $(\mathrm{mg} / \mathrm{L})$ & $3.3(4.4)$ & $4.1(6.4)$ & $\mathrm{ns}$ \\
\hline BMI & & & \\
\hline
\end{tabular}

$\mathrm{BMI}=$ Body mass index

GFR $=$ Glomerular filtration rate

$\mathrm{ACR}=$ Albumin : creatinine ratio

$\mathrm{CRP}=\mathrm{C}$-reactive protein 


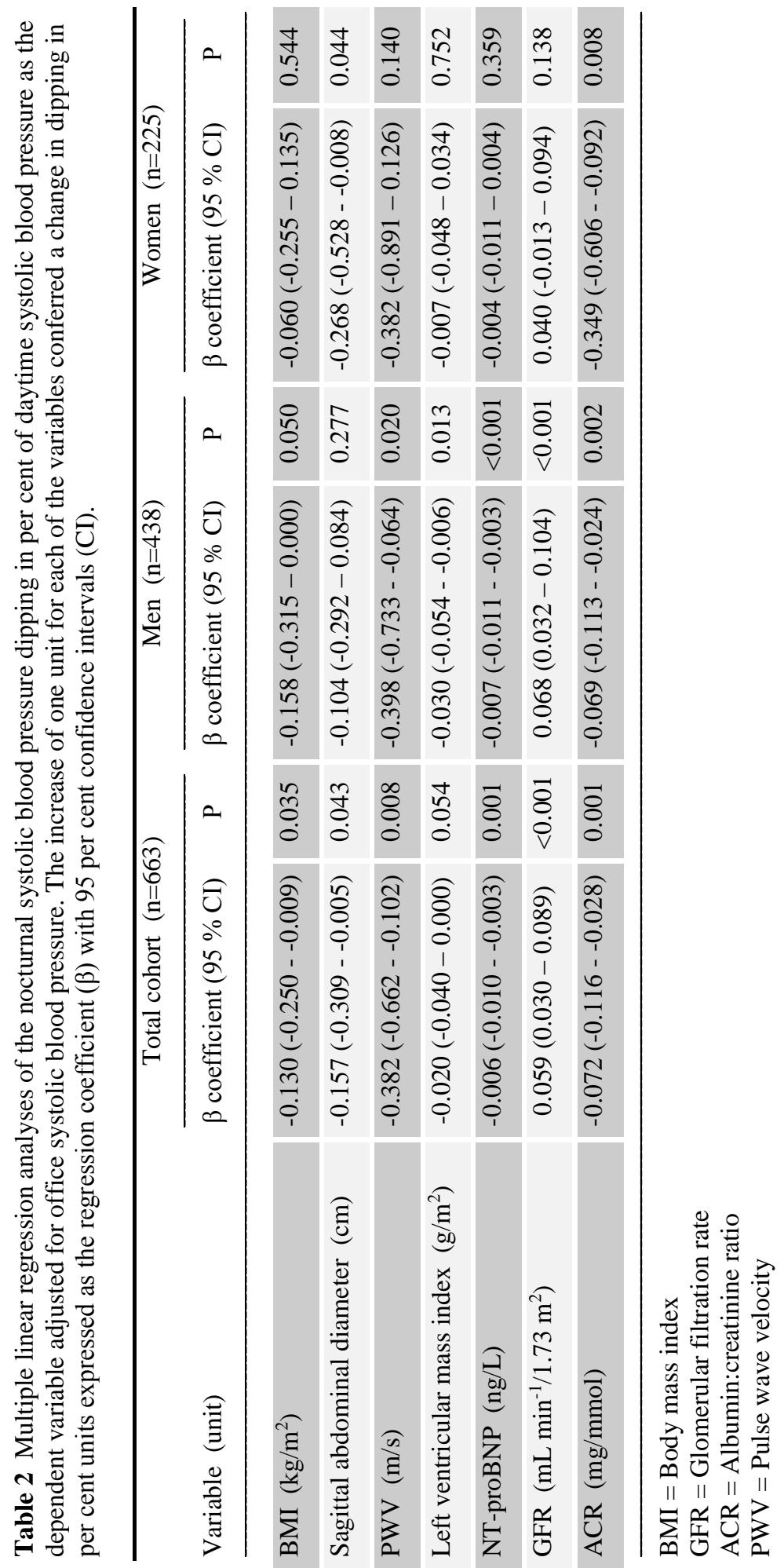




\section{Comments}

The study showed that there were significant differences in PWV, microalbuminuria, ACR, GFR and NT-proBNP between nocturnal systolic blood pressure dippers and non-dippers. There was also a significant difference between dippers versus non-dippers with respect to office systolic blood pressure. What this study adds is knowledge about circadian blood pressure variation and its association with both macro- and microvascular subclinical organ damage in an unselected cohort of patients with type 2 diabetes of whom the majority were on antihypertensive drugs but also patients with no antihypertensive medication.

The clinical implication from this study is that ambulatory blood pressure recording, which is a simple and available method in primary care, can by addressing the issue of diurnal blood pressure variation give information about early cardiovascular organ damage and microvascular complications that goes beyond effects of standardised office blood pressure measurements.

\section{Paper II}

Table 3 shows the main finding that the number of steps/day were significantly associated with lower BMI, waist circumference and sagittal abdominal diameter as well as low levels of CRP, low levels of interleukin-6 and low PWV.

Table 4 shows the association between baseline steps/day and self-reported frequency of physical exercise over a typical 7-day period. Patients with high steps/day had reported $>5 \mathrm{~h}$ exercise per week and patients who had reported no exercise had the lowest steps/day.

Figure 2 shows data on pulse wave velocity by tertiles of BMI and steps/day.

Figure 3 shows data on interleukin- 6 by tertiles of waist circumference and steps/day. 







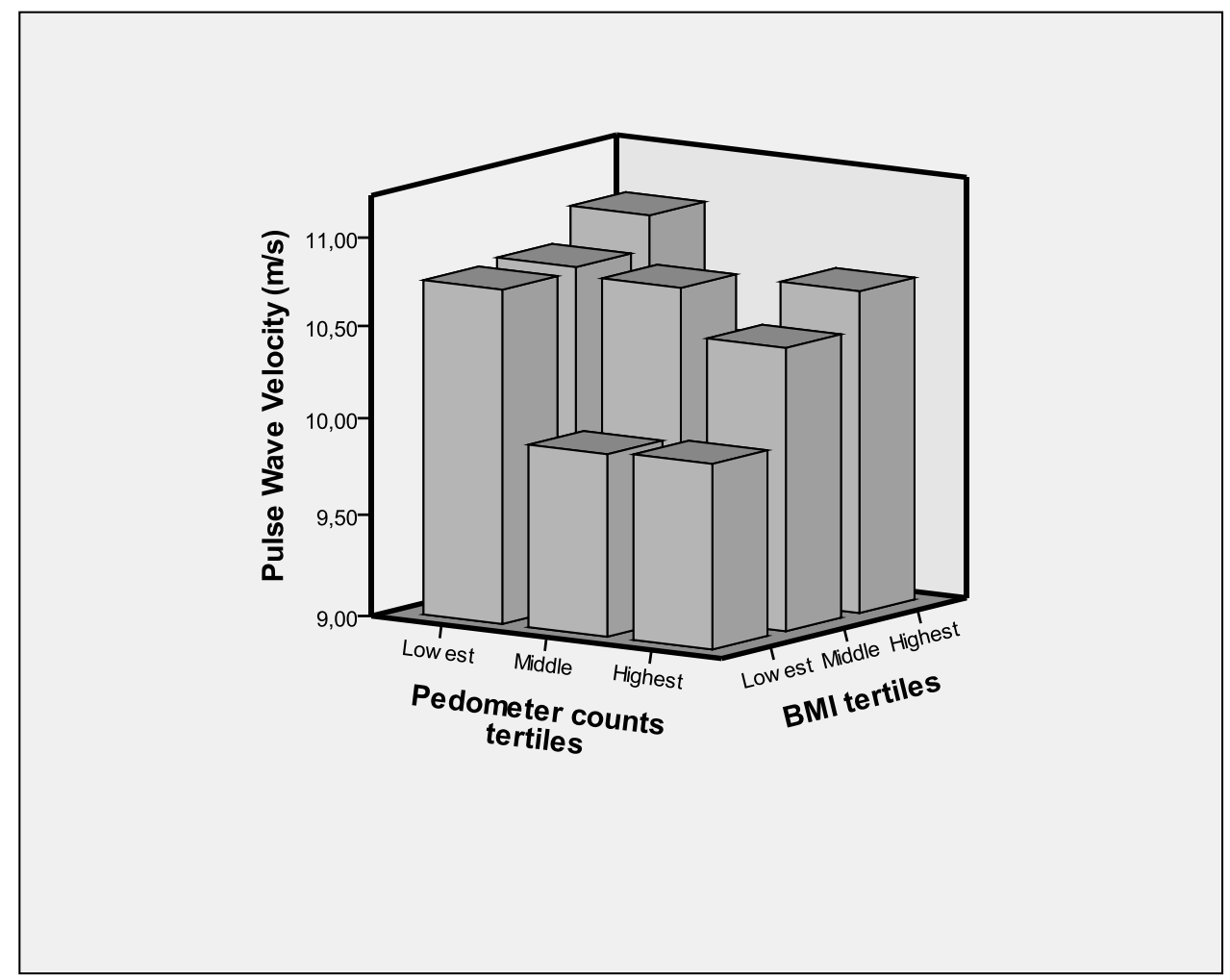

Figure 2. Pulse wave velocity (PWV) by tertiles of pedometer counts and BMI. 




Figure 3. Levels of IL-6 by tertiles of pedometer counts and waist circumference. 


\section{Comments}

We found in this observational cross-sectional study that pedometer-determined physical activity was associated not only with less general and abdominal obesity, but also with low systemic inflammation and arterial stiffness. As adipose tissue produces the pro-inflammatory cytokine interleukin-6, as well as other possibly atherogenic factors, there is a possible link between abdominal obesity and increased inflammatory response in the atherosclerotic process. It may be assumed that the association between the inflammatory markers and steps/day can be explained simply by the strong correlation between abdominal obesity and steps/day. However, this may not be entirely true at least not for interleukin-6, as the association between interleukin- 6 and steps/day remained statistically significant after adjustment for waist circumference. This independent role of inflammation is also supported by studies reporting anti-inflammatory effects of exercise training independently of weight reduction in patients with type 2 diabetes.

\section{Paper III}

Table 5 illustrates is the change in PWV ( $\triangle \mathrm{PWV}$ ) from baseline to the 4-year follow-up. The group with the lowest steps/day at baseline had a significant higher increase in $\triangle \mathrm{PWV}$ compared with group with the highest steps/day.

To further explore the associations between baseline steps/day and $\triangle \mathrm{PWV}$, we adjusted the associations for sex, age, diabetes duration, HbA1c, BMI, systolic blood pressure, PWV at baseline, $\beta$-blockers, statins, unemployment, smoking and diabetes treatment in a multivariate linear regression analysis in Table 6 and the association still remained statistically significant $(\mathrm{p}=0.005)$. We found that $23 \%$ of the variation in the study could be explained by our model. Every 1000 extra steps at baseline reduced the change in $\triangle \mathrm{PWV}$ by $0.103 \mathrm{~m} / \mathrm{s}$ between baseline and follow-up. 


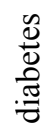

ㄱ

空

高

:

प्त

号

อ

ฮี

$\sum_{0}^{\infty}$

0
0
0
0
0
0
0
0
0
0

ป

क्षै

$\gtrsim \geq$

总

离

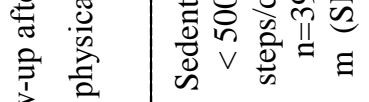

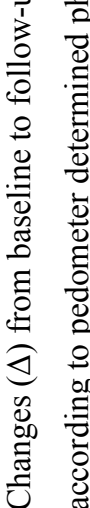

约

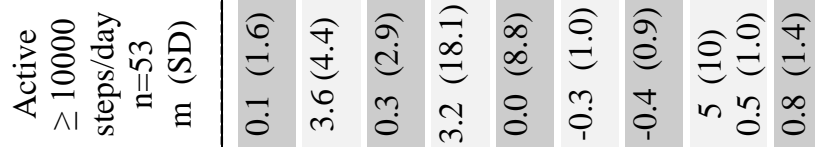



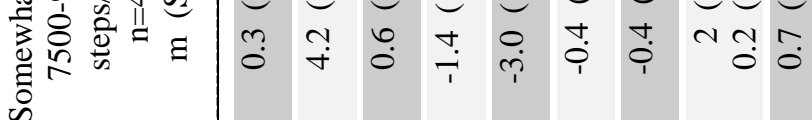

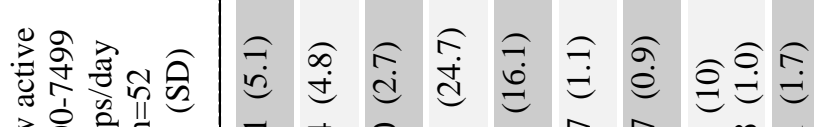



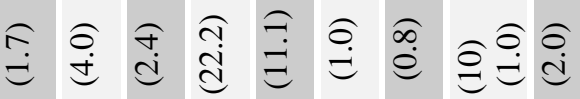

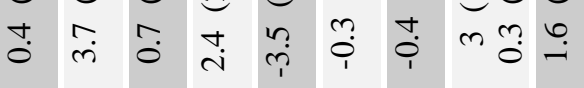

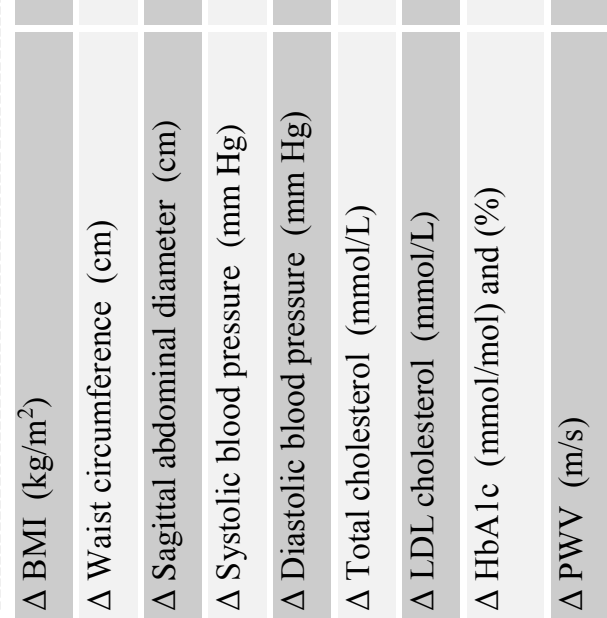

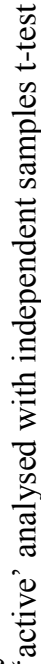

䒕气

䒕 के

莣

늉

क्षे

$\infty$

䒕气

त.

ฮี ฮี

3

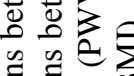

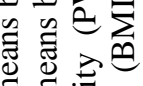

$\Xi \Xi \cdot \overline{0} x$

$\Xi . \Xi \frac{0}{0}$

के क्षे $>$

造造离

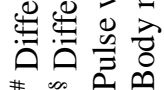




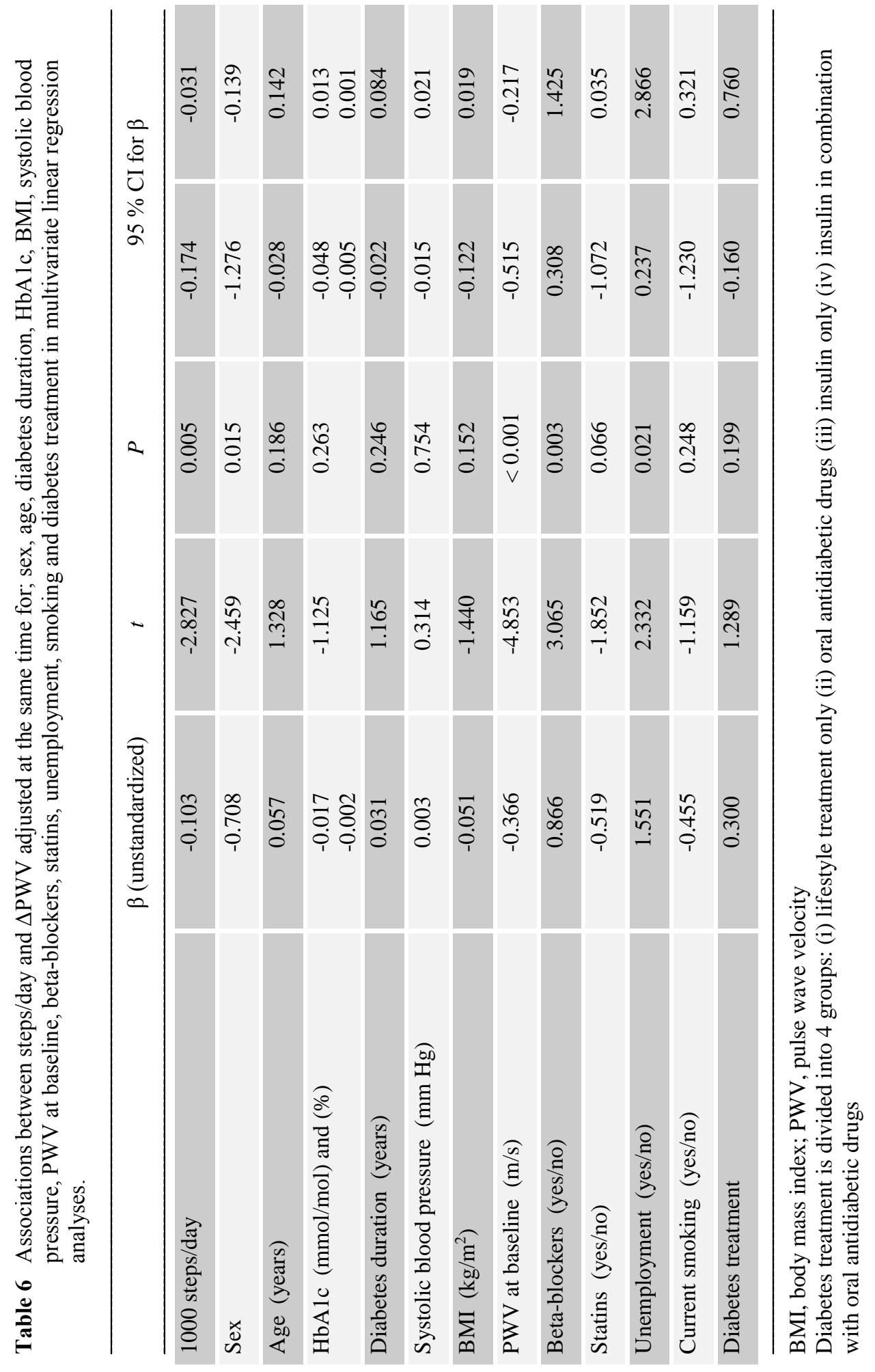




\section{Comments}

Baseline levels of daily physical activity assessed by pedometer had an inverse association with the subsequent development of arterial stiffness. High level of daily physical activity had a protective role over time independently of BMI, diabetes duration, HbA1c and systolic blood pressure. The use of pedometers is feasible in clinical practice and provides objective information about physical activity but also the future risk for subclinical organ damage.

\section{Paper IV}

Compared with 129 non-diabetic controls the 717 patients with type 2 diabetes had significantly lower levels of vitamin D but there was no significant difference concerning levels of parathyroid hormone. The patients with type 2 diabetes had also significantly higher BMI, waist circumference and ambulatory systolic blood pressure, and significantly higher PWV and intima-media thickness. In a multivariate regression model, the association between prevalent type 2 diabetes and lower vitamin D levels remained significant after adjustment for age, gender and BMI. There was no difference in mean parathyroid hormone between men and women.

Nineteen patients with type 2 diabetes reported taking vitamin supplements on a regular basis that was judged likely to contain vitamin $\mathrm{D}$ and these patients were excluded from the correlation and survival analyses, yielding a final cohort of 698 patients with type 2 diabetes. Cox regression was performed separately in men and women since gender differences are well established among several cardiovascular risk factors. During the follow-up period of a median six years, 24 men and 9 women died.

The main finding was that low vitamin D levels were associated with significantly increased risk for premature mortality in men with type 2 diabetes. This relationship was still statistically significant also when two other well-established risk markers for mortality, PWV and carotid intima-media thickness, were added to the analyses. Figure 4 shows Cox regression analysis of total mortality in men with type 2 diabetes in the upper and lower tertiles of levels of vitamin D in. High levels of parathyroid hormone were associated with significantly increased risk for premature mortality in women with type 2 diabetes. This relationship was still statistically significant also when two other well-established risk markers for mortality, PWV and carotid intima-media thickness, were added to the analyses. Figure 5 shows the corresponding analysis of mortality in women with type 2 diabetes for levels of parathyroid hormone in the higher and lower tertiles. These associations were 
independent of both traditional and new markers of risk, such as ambulatory blood pressure, PWV and carotid intima-media thickness.

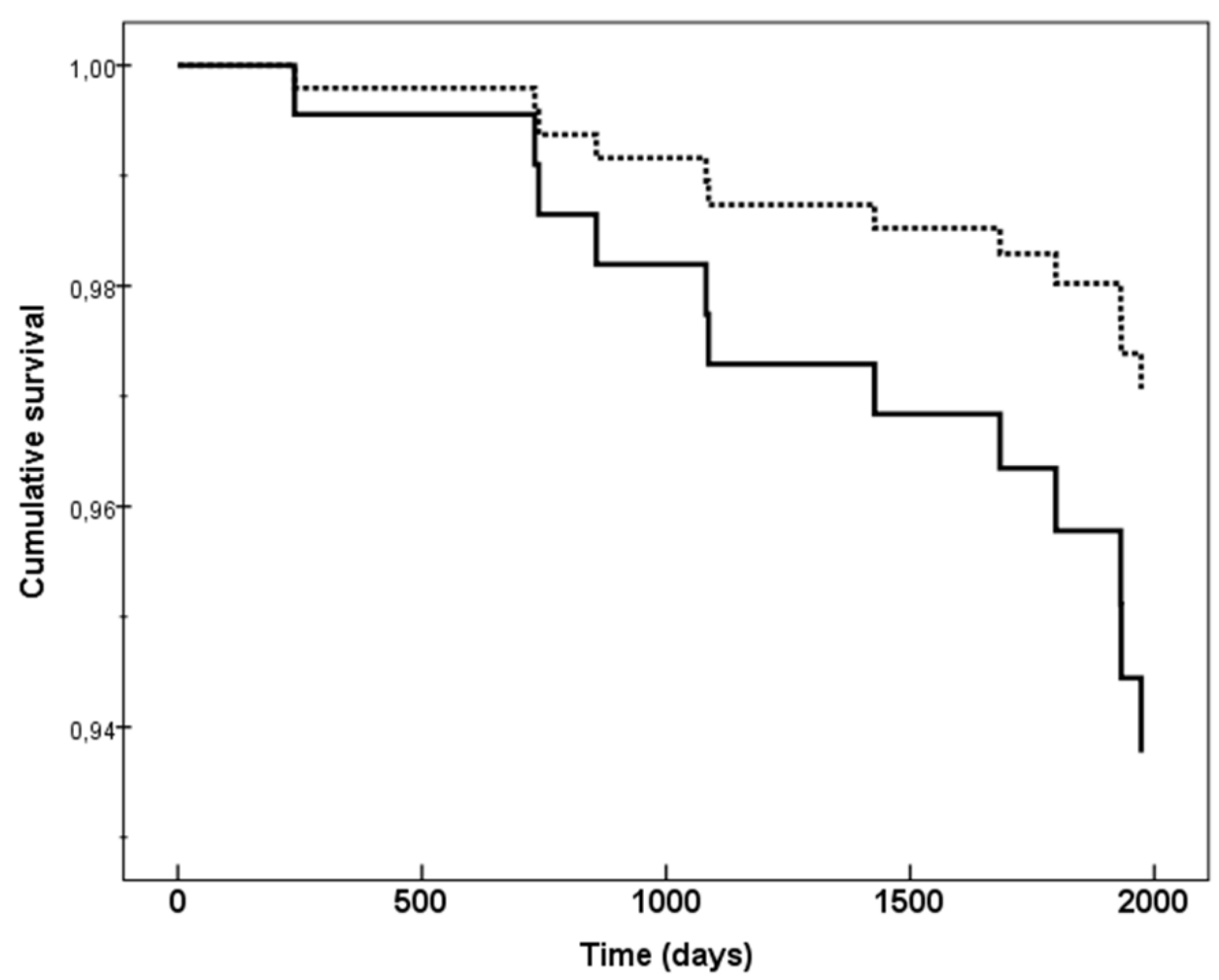

Figure 4. Cox regression analysis of total mortality in male patients with type 2 diabetes in relation to vitamin $D$ tertiles

Data are shown for upper (dashed line) and lower tertiles (continuous line) of levels of vitamin D adjusted for parathyroid hormone levels, HbA1c, waist circumference, age, 24-hour systolic ambulatory blood pressure, serum-apoB, carotid-femoral PWV and carotid IMT. 


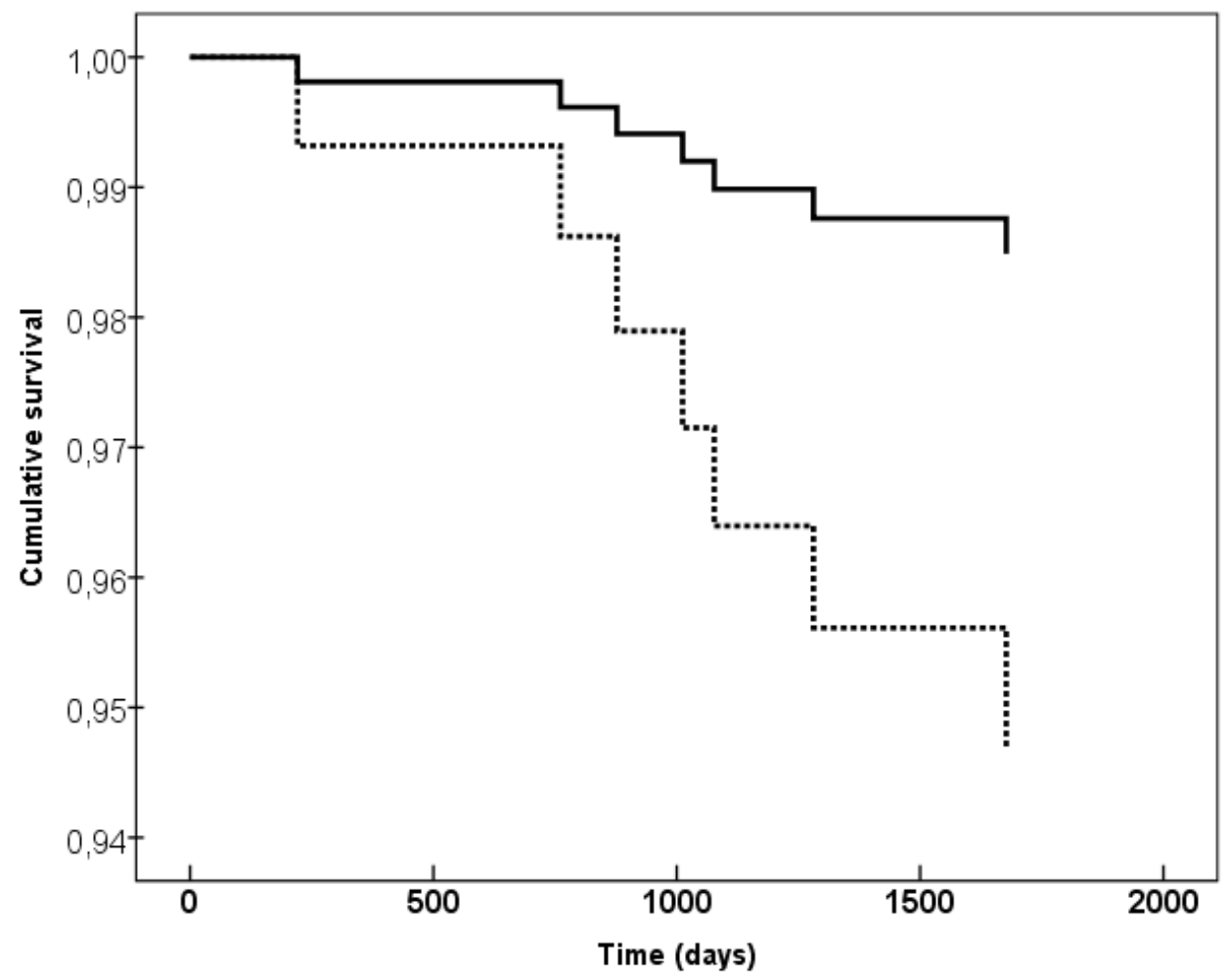

Figure 5. Cox regression analysis of total mortality in women with type 2 diabetes in relation to levels of parathyroid hormone levels

The dashed line represents upper tertile and the continuous line the risk in patients with levels in the lower tertile of parathyroid hormone levels after adjustments for levels of vitamin D, HbA1c, waist circumference, age, 24-hour systolic ambulatory blood pressure, serum-apoB, carotid-femoral PWV and carotid IMT. 


\section{Comments}

Low vitamin D levels were associated with significantly increased risk for premature mortality in men with type 2 diabetes. Likewise, high levels of parathyroid hormone were associated with significantly increased risk for premature mortality in women with type 2 diabetes. These associations were independent of both traditional and new markers of risk, such as ambulatory blood pressure, PWV and carotid intima-media thickness. In summary, low vitamin D levels in men or of high parathyroid hormone levels in women gives independent prognostic information of an increased risk for total mortality in middle-aged patients with type 2 diabetes. 


\section{DISCUSSION}

This thesis is based on data from the CARDIPP research program and CARDIPP is a large cohort of middle-aged patients with type 2 diabetes in the southern part of Sweden. The patients were recruited from primary care health centres localised in both urban and rural areas, as well as from areas with both high and low socioeconomic statuses. The aim, when planning the study, was to consequently include all patients with type 2 diabetes in the agespan 55-66 at the selected 22 primary health care centres excluding as few patients as possible.

The aim of this thesis was to cross-sectionally and prospectively analyse the associations between new aspects of cardiovascular risk factors as blood pressure, pedometer-determined physical activity and vitamin D with subclinical cardiovascular organ damage.

In summary, this thesis concludes that ambulatory blood pressure recording can by addressing the issue of diurnal blood pressure variation, explore early cardiovascular organ damage and microvascular complications that goes beyond effects of standardised office blood pressure measurements.

Furthermore, we have shown that pedometer-determined physical activity may serve as a surrogate marker for inflammation and subclinical organ damage in patients with type 2 diabetes. This finding provides novel support for the durable vascular protective role of a high level of daily physical activity, which is independent of BMI and systolic blood pressure. The use of pedometers is feasible in clinical practice and provides objective information not only about physical activity but also the future risk for subclinical organ damage in middle-aged people with type 2 diabetes.

Finally, our results indicate that low vitamin D levels in men or high parathyroid hormone levels in women give independent prognostic information of an increased risk for total mortality.

Are the results, derived from the CARDIPP research program presented in this thesis, generalizable to the vast majority of patients with type 2 diabetes? The only excluding criteria in the CARDIPP study was inability to understand Swedish and severe disease with short expected survival. Patients with previous myocardial infarction or stroke were not excluded. However, the coverage of patients recruited from each centre did differ due to local conditions. There were considerably more men compared to women included in the CARDIPP study. The main reason for this phenomenon could probably be explained by the fact that there are more men compared to women diagnosed with type 2 diabetes in the ages 55-66 years as men tend to develop type 2 diabetes at an earlier age compared to women. Considering the large number of patients included it is likely that the cohort is representative for middle-aged men and women with type 2 diabetes in Swedish primary care. 


\section{Strengths and limitations}

One strength of the CARDIPP study was the large study population recruited from 22 different health care centres and the homogeneity of the study population diminishing possible confounders due to local treatment traditions and increases the generalisability of the results. To be able to draw conclusions within reasonable time after launch of the study there was a need for intermediate endpoints. In the coming ten or more years there will be interesting data on hard endpoints as cardiovascular events and mortality in the CARDIPP cohort.

However, the CARDIPP study has several important limitations. The observational design of the study precludes any definite conclusions about causality between dipping in blood pressure or pedometer-determined physical activity on arterial stiffness.

The exact mechanism behind the effect of physical activity on cardiovascular disease is unclear and is likely to involve multiple factors as the effect on insulin sensitivity and blood pressure $(67,68)$. Some of the positive effect on physical activity intervention between active group versus placebo have been shown after many years in some studies. The follow-up after four years in CARDIPP may be too short time. Furthermore, non-vigorous level of physical activity may be more frequent in participants with an impaired health condition per se compared with participants who chose to be more physically active. It was not possible to adjust for some potentially important confounders such as the intensity of physical activity, compliance and dietary data. The follow-up response rate of $57 \%$ after four years was also a limitation. Furthermore, the number of days during which pedometer-data was obtained was lower in CARDIPP compared to some other studies in the field (76).

The observational design also precludes any definite conclusions about causality between vitamin D, parathyroid hormone and mortality, respectively. Only the total mortality has been studied even if the cardiovascular mortality is the most important.

\section{Clinical implications and future research}

In Sweden, patients with type 2 diabetes are treated in primary care by general practitioners and nurses especially educated in diabetes care. Patients with type 2 diabetes represent a group of resource demanding, aging patients with a lot of co-morbidity. There is a need to perform studies in patients with type 2 diabetes in primary care by primary care physicians and nurses in order to use feasible tools and markers in the context of primary care and patients with complex co-morbidities.

The clinical implications of the results from the study with ambulatory blood pressure and the diurnal systolic blood pressure pattern is that 24 hours monitoring gives additional and independent information on sub-clinical organ damage. A non-dipping pattern indicates more arterial stiffness and sub-clinical damage of the kidneys. Therefore, it is important with strict 
blood pressure control to avoid further damage and also to avoid cardiovascular events in these patients with higher risk.

The results from the study of pedometer-determined physical activity indicate that physically active patients have less arterial stiffness and lower grade of inflammation and therefore probably have a better prognosis in terms of cardiovascular disease compared with less active patients. The use of pedometers is feasible in clinical practice and provides objective information not only about physical activity but also the future risk for subclinical organ damage in middle-aged people with type 2 diabetes.

We need randomised clinical trials to investigate the roll of vitamin D. Five trials including 2150-20 000 patients aged 50 years or older are in progress, testing whether vitamin D supplementation at 40-80 $\mu \mathrm{g}$ per day can reduce the risk of cancer, cardiovascular diseases, diabetes mellitus, infections, declining cognitive functions, and fractures (133). Even if the Look Ahead trial was stopped early on the basis of a futility analysis there is a need for more prospective and randomised trials to determine the value of intervention with physical activity. 


\section{CONCLUSIONS}

\section{General conclusion}

Pedometer-determined physical activity and the nocturnal dipping of systolic blood pressure is associated with the arterial stiffness in middle-aged patients with type 2 diabetes. The levels of vitamin D and parathyroid hormone give information about the risk for premature all-cause mortality in middle-aged patients with type 2 diabetes, gender specifically.

\section{Specific conclusions}

- By addressing the issue of diurnal systolic blood pressure variation, the use of ambulatory blood pressure recording adds additional information about prevalent cardiovascular organ damage and microvascular complications that goes beyond the information of standardised office blood pressure measurements.

- Pedometer-determined physical activity may serve as a surrogate marker for inflammation and subclinical organ damage in patients with type 2 diabetes.

- Baseline levels of daily physical activity assessed by pedometer showed an inverse association with the subsequent risk of arterial stiffness which was consistent after four years of follow-up.

- Low vitamin D levels in men and high parathyroid hormone levels in women were associated with an increased risk for total mortality. 


\section{POPULÄRVETENSKAPLIG SAMMANFATTNING}

Diabetes typ 2 är en kronisk folksjukdom som blir vanligare över hela världen och de främsta orsakerna är övervikt och för lite fysisk aktivitet. Oftast har sjukdomen en smygande debut utan symptom tidigt i förloppet. Personer som drabbas av diabetes typ 2 har en ökad sjuklighet och för tidig död jämfört med friska individer. Den vanligaste dödsorsaken är hjärtkärlsjukdomar och individer i medelåldern med diabetes typ 2 har åtminstone fördubblad risk att drabbas av hjärtinfarkt och stroke.

För att kunna påbörja och individuellt anpassa förebyggande behandling som motverkar denna förhöjda risk är det viktigt att ha kliniskt lättillgängliga och tillförlitliga riskmarkörer för hjärt-kärlsjukdom. Väletablerade och i stora randomiserade kliniska studier väldokumenterade riskmarfaktorer är blodtryck, blodfetter, övervikt och rökning. Om dessa riksfaktorer motverkas minskar risken för hjärt-kärlsjukdom. Hjärt-kärlsjukdom orsakas av ateroskleros som består av en tilltagande stelhet och förträngning av blodkärlen.

Syftet med den här avhandlingen var att utvärdera nya riskmarkörer för hjärt-kärlsjukdom hos patienter med diabetes typ 2. Studien har genomförts på 22 vårdcentraler i Östergötland och Jönköping och sammanlagt 761 patienter med diabetes typ 2 i åldern 55-66 år deltog. Efter fyra år genomfördes en återundersökning av samtliga patienter. En kontrollgrupp med individer utan diabetes typ 2 undersöktes också.

I delarbete I mättes blodtrycket med automatisk blodtrycksmätning i ett dygn. Delarbete I visade att patienter som inte sjönk i sitt blodtryck nattetid hade mer tecken på tidig kärlstelhet, förstorad hjärtmuskel och nedsatt njurfunktion jämfört med patienter med normal nattlig blodtryckssänkning.

Delarbete II och III visade att med stegräknare definierat fysisk aktiva patienter med diabetes typ 2 hade mindre kärlstelhet jämfört med inaktiva och stillasittande. Denna effekt sågs både vid den första tvärsnittsundersökningen samt vid återundersökningen efter fyra år.

Delarbete IV visade att låga nivåer av vitamin D hos män med diabetes typ 2 var förenat med ökad risk för tidig död. Höga nivåer av paratyroideahormon hos kvinnor med diabetes typ 2 var förenat med ökad risk för tidig död. 


\section{ACKNOWLEDGEMENTS}

I would like to express my warmest gratitude to everyone who helped me and contributed to this dissertation. Especially thanks to:

Carl Johan Östgren, professor, my head supervisor, for excellent knowledge in diabetes research and general practice and also great encouragement and devotion during the years of work with this thesis.

Fredrik Nyström, professor, my supervisor, for excellent knowledge in cardiovascular and diabetes research and for scrutinizing every line in our manuscripts.

Toste Länne, professor, my supervisor, for excellent knowledge in cardiovascular research and for all support with the clinical cardiovascular examinations.

Anna-Karin Schöld, research nurse, for lots of help with the data-base and the freezers.

Catharina Linderoth for good administrative assistance.

Karin Festin, statistician, for excellent statistical guidance.

Hans Guldbrand, my colleague at Vårdcentralen Lyckorna, for great encouragement, collaboration and friendship.

Yvonne Lövgren, former head of Vårdcentralen Lyckorna, for enthusiasm and encouragement and for making it possible for me to combine research with daily clinical practice.

Thomas Åhlander, present head of Vårdcentralen Lyckorna, for enthusiasm and encouragement and for making it possible for me to combine research with daily clinical practice.

Christina Andersson and Ingrid Carlegrim, diabetes nurses, for recruiting study participants.

Co-writers and all colleagues in the CARDIPP project for good collaboration.

All colleagues and coworkers at Vårdcentralen Lyckorna, for friendly support and interest. 


\section{REFERENCES}

1. Guariguata L, Whiting DR, Hambleton I, Beagley J, Linnenkamp U, Shaw JE. Global estimates of diabetes prevalence for 2013 and projections for 2035. Diabetes Res Clin Pract 2014;103(2):137-49.

2. Whiting DR, Guariguata L, Weil C, Shaw J. IDF diabetes atlas: global estimates of the prevalence of diabetes for 2011 and 2030. Diabetes Res Clin Pract 2011;94(3):311-21.

3. Jansson SP, Fall K, Brus O, Magnusson A, Wändell P, Östgren CJ, Rolandsson O. Prevalence and incidence of diabetes mellitus: a nationwide population-based pharmacoepidemiological study in Sweden. Diabet Med 2015;32(10):1319-28.

4. Mathers CD, Loncar D. Projections of global mortality and burden of disease from 2002 to 2030. PLoS Med 2006;3(11):e442.

5. Tancredi M, Rosengren A, Svensson AM, Kosiborod M, Pivodic A, Gudbjörnsdottir S et al. Excess Mortality among Persons with Type 2 Diabetes. N Engl J Med 2015;373(18):172032.

6. Eberly LE, Cohen JD, Prineas R, Yang L; Intervention Trial Research group. Impact of incident diabetes and incident nonfatal cardiovascular disease on 18-year mortality: the multiple risk intervention trial experience. Diabetes Care 2003;26(3):848-54.

7. Wild SH, Smith FB, Lee AJ, Fowkes FG. Criteria for previously undiagnosed diabetes and risk of mortality: 15-year follow-up of the Edinburgh Artery Study cohort. Diabet Med 2005;22(4):490-6.

8. Guzder RN, Gatling W, Mullee MA, Byrne CD. Early mortality from the time of diagnosis of Type 2 diabetes: a 5-year prospective cohort study with a local age- and sex-matched comparison cohort. Diabet Med 2007;24(10):1164-7.

9. Guzder RN, Gatling W, Mullee MA, Byrne CD. Impact of metabolic syndrome criteria on cardiovascular risk in people with newly diagnosed type 2 diabetes. Diabetologia 2006;49(1):49-55.

10. Triplitt CL. Examining the mechanisms of glucose regulation. Am J Manag Care 2012;18(1 Suppl):S4-10.

11. Wasserman DH. Four grams of glucose. Am J Physiol Endocrinol Metab 2009;296(1):E11-21.

12. Gerich JE. Physiology of glucose homeostasis. Diabetes Obes Metab 2000;2(6):345-50. 
13. Leahy JL. Pathogenesis of type 2 diabetes mellitus. Arch Med Res 2005;36(3):197-209.

14. Stumvoll M, Goldstein BJ, van Haeften TW. Type 2 diabetes: principles of pathogenesis and therapy. Lancet 2005;365(9467):1333-46.

15. Report of the Expert Committee on the Diagnosis and Classification of Diabetes Mellitus. Diabetes Care 1997;20(7):1183-97.

16. Diagnosis and Classification of Diabetes Mellitus. Diabetes Care 2013;36 Suppl 1:S67-74.

17. Bellamy L, Casas JP, Hingorani AD, Williams D. Type 2 diabetes mellitus after gestational diabetes: a systematic review and meta-analysis. Lancet 2009;373(9677):1773-9.

18. Alberti KG, Zimmet PZ. Definition, diagnosis and classification of diabetes mellitus and its complications. Part 1: diagnosis and classification of diabetes mellitus provisional report of a WHO consultation. Diabet Med 1998;15(7):539-53.

19. The Committee of the Japan Diabetes Society on the Diagnostic Criteria of Diabetes Mellitus, Seino Y, Nanjo K, Tajima N, Kadowaki T, Kashiwagi A, Araki E et al. Report of the Committee on the Classification and Diagnostic Criteria of Diabetes Mellitus. J Diabetes Investig 2010;1(5):212-28.

20. International Expert Committee. International Expert Committee report on the role of the A1C assay in the diagnosis of diabetes. Diabetes Care 2009;32(7):1327-34.

21. Hellgren MI, Daka B, Jansson PA, Lindblad U. Primary care screening for individuals with impaired glucose metabolism with focus on impaired glucose tolerance. Prim Care Diabetes 2015;9(4):261-6.

22. Drivsholm T, de Fine Olivarius N, Nielsen AB, Siersma V. Symptoms, signs and complications in newly diagnosed type 2 diabetic patients, and their relationship to glycaemia, blood pressure and weight. Diabetologia 2005;48(2):210-4.

23. Bano G. Glucose homeostatis, obesity and diabetes. Best Pract Res Clin Obstet Gynaecol 2013;27(5):715-26.

24. Chang-Chen KJ, Mullur R, Bernal-Mizrachi E. Beta-cell failure as a complication of diabetes. Rev Endocr Metab Disord 2008;9(4):329-43.

25. Harrison TA, Hindorff LA, Kim H, Wines RC, Bowen DJ, McGrath BB, Edwards KL. Family history of diabetes as a potential public health tool. Am J Prev Med 2003;24(2):152-9.

26. Hemminki K, Li X, Sundquist K, Sundquist J. Familial risks for type 2 diabetes in Sweden. Diabetes Care 2010;33(2):293-7. 
27. Wikner C, Gigante B, Hellénius ML, de Faire U, Leander K. The risk of type 2 diabetes in men is synergistically affected by parental history of diabetes and overweight. PLoS One 2013;8(4):e61763.

28. Newman B, Selby JV, King MC, Slemenda C, Fabsitz R, Friedman G. Concordance for type 2 (non-insulin-dependent) diabetes mellitus in male twins. Diabetologia 1987;30(10):763-8.

29. Alberti KG, Zimmet P, Shaw J. Metabolic syndrome - a new world-wide definition. A Consensus Statement from the International Diabetes Federation. Diabet Med 2006;23(5):469-80.

30. Eckel RH, Grundy SM, Zimmet PZ. The metabolic syndrome. Lancet 2005;365(9468):1415-28.

31. Gallagher EJ, Leroith D, Karnieli E. The metabolic syndrome - from insulin resistance to obesity and diabetes. Med Clin North Am 2011;95(5):855-73.

32. Grundy SM. Metabolic syndrome pandemic. Arterioscler Thromb Vasc Biol 2008;28(4):629-36.

33. Grundy SM. Metabolic syndrome: a multiplex cardiovascular risk factor. J Clin Endocrinol Metabol 2007;92(2):399-404.

34. Alberti KG, Eckel RH, Grundy SM, Zimmet PZ, Cleeman JI, Donato KA et al. Harmonizing the metabolic syndrome: a joint interim statement of the International Diabetes Federation Task Force on Epidemiology and Prevention; National Heart, Lung, and Blood Institute; American Heart Association; World Heart Federation; International Atherosclerosis Society; and International Association for the Study of Obesity. Circulation 2009;120(16):1640-5.

35. Ford ES, Li C, Sattar N. Metabolic syndrome and incident diabetes: current state of the evidence. Diabetes Care 2008;31(9):1898-904.

36. Mottillo S, Filion KB, Genest J, Joseph L, Pilote L, Poirier S et al. The metabolic syndrome and cardiovascular risk a systematic review and meta-analysis. J Am Coll Cardiol 2010;56(14):1113-32.

37. He Z, King GL. Microvascular complications of diabetes. Endocrinol Metab Clin North Am 2004;33(1):215-38.

38. Tarr JM, Kaul K, Wolanska K, Kohner EM, Chibber R. Retinopathy in diabetes. Adv Exp Med Biol 2012;771:88-106.

39. Chistiakov DA. Diabetic retinopathy: pathogenic mechanisms and current treatment.

Diabetes Metab syndr 2011;5(3):165-72. 
40. Tanaka S, Tanaka S, Iimuro S, Yamashita H, Katayama S, Akanuma Y et al. Predicting macro- and microvascular complications in type 2 diabetes: the Japan Diabetes Complications Study/the Japanese Elderly Diabetes Intervention Trial risk engine. Diabetes Care 2013;36(5):1193-9.

41. Kelly T, Yang W, Chen CS, Reynolds K, He J. Global burden of obesity in 2005 and projections to 2030. Int J Obes (Lond) 2008;32(9):1431-7.

42. Mokdad AH, Ford ES, Bowman BA, Dietz WH, Vinicor F, Bales VS, Marks JS. Prevalence of obesity, diabetes, and obesity-related health risk factors, 2001. JAMA 2003;289(1):76-9.

43. Chan JM, Rimm EB, Colditz GA, Stampfer MJ, Wilett WC. Obesity, fat distribution, and weight gain as risk factors for clinical diabetes in men. Diabetes Care 1994;17(9):961-9.

44. Hanley AJ, Wagenknecht LE, Norris JM, Bryer-Ash M, Chen YI, Anderson AM et al. Insulin resistance, beta cell dysfunction and visceral adiposity as predictors of incident diabetes: the Insulin Resistance Atherosclerosis Study (IRAS) Family study. Diabetologia 2009;52(10):2079-86.

45. Keys A, Fidanza F, Karvonen MJ, Kimura N, Taylor HL. Indices of relative weight and obesity. Int J Epidemiol 2014;43(3):655-65.

46. GBD 2013 Risk Factors Collaborators, Forouzanfar MH, Alexander L, Anderson HR, Bachman VF, Biryukov S, Brauer M et al. Global, regional, and national comparative risk assessment of 79 behavioral environmental and occupational, and metabolic risks or clusters of risks in 188 countries, 1990-2013: a systemic analysis for the Global Burden of Disease Study 2013. Lancet 2015;386(10010):2287-323.

47. Lean ME, Han TS, Deurenberg P. Predicting body composition by densitometry from simple anthropometric measurements. Am J Clin Nutr 1996;63(1):4-14.

48. Petersson H, Daryani A, Risérus U. Sagittal abdominal diameter as a marker of inflammation and insulin resistance among immigrant women from the Middle East and native Swedish women: a cross-sectional study. Cardiovasc Dibetolo 2007;6:10.

49. Risérus U, Arnlöv J, Brismar K, Zethelius B, Berglund L, Vessby B. Sagittal abdominal diameter is a strong anthropometric marker of insulin resistance and hyperproinsulinemia in obese men. Diabetes Care 2004;27(8):2041-6.

50. Dahlén EM, Bjarnegård N, Länne T, Nystrom FH, Ostgren CJ. Sagittal abdominal diameter is a more independent measure compared with waist circumference to predict stiffness in subjects with type 2 diabetes - a prospective observational cohort study. Cardiovasc Diabetol 2013;12:55. 
51. Thomas DE, Elliott EJ, Naughton GA. Exercise for type 2 diabetes mellitus. Cochrane Database Syst Rev 2006;(3):CD002968.

52. Boulé NG, Haddad E, Kenny GP, Wells GA, Sigal RJ. Effects of exercise on glycemic control and body mass in type 2 diabetes mellitus: a meta-analysis of controlled clinical trials. JAMA 2001;286(10):1218-27.

53. Blair SN. Physical inactivity: the biggest public health problem of the $21^{\text {st }}$ century. $\mathrm{Br} \mathrm{J}$ Sports Med 2009;43(1):1-2.

54. Lee IM, Shiroma EJ, Lobelo F, Puska P, Blair SN, Katzmarzyk PT; Lancet Physical Activity Series Working Group. Effect of physical inactivity on major non-communicable diseases worldwide: an analysis of burden of disease and life expectancy. Lancet 2012;380(9338):219-29.

55. Edwardson CL, Gorely T, Davies MJ, Gray LJ, Khunit K, Wilmot EG et al. Association of sedentary behaviour with metabolic syndrome: a meta-analysis. PLoS One 2012;7(4):e34916.

56. Laaksonen DE, Lindström J, Lakka TA, Eriksson JG, Niskanen L, Wikström K et al. Physical activity in the prevention of type 2 diabetes: the Finnish diabetes prevention study. Diabetes 2005;54(1):158-65.

57. Jeon CY, Lokken RP, Hu FB, van Dam RM. Physical activity of moderate intensity and risk of type 2 diabetes: a systematic review. Diabetes Care 2007;30(3):744-52.

58. Ekblom-Bak E, Hellénius ML, Ekblom O, Engström LM, Ekblom B. Independent associations of physical activity and cardiovascular fitness with cardiovascular risk in adults. Eur J Cardiovasc Prev Rehabil 2010;17(2):175-80.

59. Wilmot EG, Edwardson CL, Achana FA, Davies MJ, Gorely T, Gray LJ et al. Sedentary time in adults and the association with diabetes, cardiovascular disease and death: systematic review and meta-analysis. Diaetologia 2012;55(11):2895-905.

60. Ford ES, Herman WH. Leisure-time physical activity patterns in the U.S. diabetic population. Findings from the 1990 National Health Interview Survey - Health Promotion and Disease Prevention Supplement. Diabetes Care 1995;18(1):27-33.

61. Matthews CE, Chen KY, Freedson PS, Buchowski MS, Beech BM, Pate RR, Troiano RP. Amount of time spent in sedentary behaviors in the United States, 2003-2004. Am J Epidemiol 2008;167(7):875-81.

62. Healy GN, Matthews CE, Dunstan DW, Winkler EA, Owen N. Sedentary time and cardio-metabolic biomarkers in US adults: NHANES 2003-2006. Eur Heart J 2011;32(5):5907.

63. Ross R. Atherosclerosis - an inflammatory disease. N Engl J Med 1999;340(2):115-26. 
64. Yeh ET, Willerson JT. Coming of age of C-reactive protein: using inflammation in cardiology. Circulation 2003;107(3):370-1.

65. Kasapis C, Thompson PD. The effects of physical activity on serum C-reactive protein and inflammatory makers: a systematic review. J Am Coll Cardiol 2005;45(10):1563-9.

66. Albert MA, Glynn RJ, Ridker PM. Effect of physical activity on serum C-reactive protein. Am J Cardiol 2004;93(2):221-5.

67. Mora S, Cook N, Buring JE, Ridker PM, Lee IM. Physical activity and reduced risk of cardiovascular events: potential mediating mechanisms. Circulation 2007;116(19):2110-8.

68. Huai P, Xun H, Reilly KH, Wang Y, Ma W, Xi B. Physical activity and risk of hypertension: a meta-analysis of prospective cohort studies. Hypertension 2013;62(6):1021-6.

69. Jeon CY, Lokken RP, Hu FB, van Dam RM. Physical activity of moderate intensity and risk of type 2 diabetes: a systemic review. Diabetes Care 2007;30(3):744-52.

70. Huai P, Xun H, Reilly KH, Wang Y, Ma W, Xi B. Physical activity and risk of hypertension: a meta-analysis of prospective cohort studies. Hypertension 2013;62(6):1021-6.

71. Balk EM, Earley A, Raman G, Avendano EA, Pittas AG, Remington PL. Combined Diet and Physical Activity Promotion Programs to Prevent Type 2 Diabetes Among Persons at Increased Risk: A Systematic Review for the Community Preventive Services Task Force. Ann Intern Med 2015;163(6):437-51.

72. Ekblom-Bak E, Ekblom B, Vikström M, de Faire U, Hellénius ML. The importance of non-exercise physical activity for cardiovascular health and longevity. Br J Sports Med 2014;48(3):233-8.

73. Pan XR, Li GW, Hu YH, Wang JX, Wang WY, An ZX et al. Effects of diet and exercise in preventing NIDDM in people with impaired glucose tolerance. The Da Qing IGT and Diabetes Study. Diabetes Care 1997;20(4):537-44.

74. Tumilehto J, Lindström J, Eriksson JG, Valle TT, Hämäläinen H, Ilanne-Parikka P et al. Prevention of type 2 diabetes mellitus by changes in lifestyle among subjects with impaire glucose tolerance. N Engl J Med 2001;344(18): 1343-50.

75. Knowler WC, Barrett-Connor E, Fowler SE, Hamman RF, Lachin JM, Walker EA et al. Reduction in the incidence of type 2 diabetes with lifestyle intervention or metformin. N Engl J Med 2002;346(6):393-403.

76. Yates T, Haffner SM, Schulte PJ, Thomas L, Huffman KM, Bales CW et al. Association between change in daily ambulatory activity and cardiovascular events in people with impaired glucose tolerance (NAVIGATOR trial): a cohort analysis. Lancet 2014;383(9922):1059-66. 
77. Li G, Zhang P, Wang J, Gregg EW, Yang W, Gong Q et al. The long-term effect of lifestyle interventions to prevent diabetes in the China Da Qing Diabetes Prevention Study: a 20-year follow-up study. Lancet 2008;371(9626):1783-9.

78. Li G, Zhang P, Wang J, An Y, Gong Q, Gregg EW et al. Cardiovascular mortality, allcause mortality, and diabetes incidence after lifestyle intervention for people with impaired glucose tolerance in the Da Qing Diabetes Prevention Study: a 23-year follow-up study. Lancet Diabetes Endocrinol 2014;2(6):474-80.

79. Laaksonen DE, Lindström J, Lakka TA, Eriksson JG, Niskanen L, Wikström K et al. Physical activity in the prevention of type 2 diabetes: the Finnish diabetes prevention study. Diabetes 2005;54(1):158-65.

80. Uusitupa M, Peltonen M, Lindström J, Aunola S, Ilanne-Parikka P, KeinänenKiukaanniemi S et al. Ten-year mortality and cardiovascular morbidity in the Finnish Diabetes Prevention Study - secondary analysis of the randomized trial. PLoS One 2009;4(5):e5656.

81. Diabetes Prevention Program Research Group, Knowler WC, Fowler SE, Hamman RF, Christophi CA, Hoffman HJ, Brenneman AT et al. 10-year follow-up of diabetes incidence and weight loss in the Diabetes Prevention Program Outcomes Study. Lancet 2009;374(9702):1677-86.

82. Diabetes Prevention Program Research Group. Long-term effects of lifestyle intervention or metformin on diabetes development and microvascular complications over 15-year followup: the Diabetes Prevention Program Outcomes Study. Lancet Diabetes Endocrinol 2015;3(11):866-75.

83. Look AHEAD Research group, Wing RR, Bolin P, Brancati FL, Bray GA, Clark JM, Coday $\mathrm{M}$ et al. Cardiovascular effects on intensive lifestyle intervention in type 2 diabetes. $\mathrm{N}$ Engl Med 2013;369(2):145-54.

84. Tudor-Locke CE, Myers AM. Challenges and opportunities for measuring physical activity in sedentary adults. Sports Med 2001;31(2):91-100.

85. Tudor-Locke CE, Myers AM. Methodological considerations for researchers and practitioners using pedometers to measure physical (ambulatory) activity. Res Q Exerc Sport 2001;72(1):1-12.

86. Tudor-Locke C, Burkett L, Reis JP, Ainsworth BE, Macera CA, Wilson DK. How many days of pedometer monitoring predict weekly physical activity in adults? Prev Med 2005;40(3):293-8.

87. Yamanouchi K, Shinozaki T, Chikada K, Nishikawa T, Ito K, Shimizu S et al. Daily walking combined with diet therapy is a useful means for obese NIDDM patients not only to reduce body weight but also to improve insulin sensitivity. Diabetes Care 1995;18(6):775-8. 
88. Tudor-Locke C, Swift DL, Schuna JM jr, Dragg AT, Davis AB, Martin CK et al. WalkMore: a randomized controlled trial of pedometer-based interventions differing on intensity messages. BMC Public Health 2014;14:168.

89. Tudor-Locke C, Washington TL, Hart TL. Expected values for steps/day in special populations. Prev Med 2009;49(1):3-11.

90. Tudor-Locke CE, Bell RC, Myers AM, Harris SB, Lauzon N, Rodger NW. Pedometerdetermined ambulatory activity in individuals with type 2 diabetes. Diabetes Res Clin Pract 2002;55(3):191-9.

91. Tudor-Locke C, Basset DR Jr. How many steps/day are enough? Preliminaary pedometer indices for public health. Sports Med 2004;34(1):1-8.

92. Tudor-Locke C, Leonardi C, Johnson WD, Katzmazyk PT, Church TS. Accelerometer steps/day translation of moderate-to-vigorous activity. Prev Med 2011;53(1-2):31-3.

93. Tudor-Locke C, Ainsworth BE, Whitt MC, Thompson RW, Addy CL, Jones DA. The relationship between pedometer-determined ambulatory activity and body composition variables. Int J Obes Relat Metab Disord 2001;25(11):1571-8.

94. Iwane M, Arita M, Tomimoto S, Satani O, Matsumoto M, Miyashita K, Nishio I. Walking 10,000 steps/day or more reduces blood pressure and sympathetic nerve activity in mild essential hypertension. Hypertension Res 2000;23(6):573-80.

95. Dwyer T, Ponsonby AL, Ukoumunne OC, Pezic A, Venn A, Dunstan D et al. Association of change in daily step count over five years with insulin sensitivity and adiposity: population based cohort study. BMJ 2011;342:c7249.

96. Mourad JJ, Le Jeune S. Blood pressure control, risk factors and cardiovascular prognosis in patients with diabetes: 30 years of progress. J Hypertension Suppl 2008;26(3):S7-13.

97. Sowers JR, Epstein M, Frohlich ED. Diabetes, hypertension, and cardiovascular disease: an update. Hypertension 2001;37(4):1053-9.

98. Mancia G, Fagard R, Narkiewicz K, Redon J Zanchetti A, Böhm M et al. 2013 ESH/ESC Practice Guidelines for the Management or Arterial Hypertension. Blood Press 2014;23(1):316.

99. Weber MA, Schiffrin EL, White WB, Mann S, Lindholm LH, Kenerson JG et al. Clinical practice guidelines for the management of hypertension in the community: a statement by the American Society of Hypertension and the International Society of Hypertension. J Clin Hypertens (Greenwich) 2014;16(1):14-26.

100. SPRINT Research Group, Wright JT Jr, Williamson JD, Whelton PK, Snyder JK, Sink KM, Rocco MV et al. A Randomized Trial of Intensive versus Standard Blood-Pressure Control. N Engl J Med 2015;373(22):2103-16. 
101. Cardoso CR, Leite NC, Muxfeldt ES, Salles GF. Thresholds of ambulatory blood pressure associated with chronic complications in type 2 diabetes. Am J Hypertens 2012;25(1):82-8.

102. Verdecchia P, Schillaci G, Borgioni C, Ciucci A, Pede S, Porcellati C. Ambulatory pulse pressure: a potent predictor of total cardiovascular risk in hypertension. Hypertension 1998;32(6):983-8.

103. Mannucci E, Lambertucci L, Monami M, Fedeli A, Chiasserini V, Marchionni N et al. Pulse pressure and mortality in hypertensive type 2 diabetic patients. A cohort study. Diabetes Metab Res Rev 2006;22(3):172-5.

104. Eguchi K, Pickering TG, Hoshide S, Ishikawa J, Ishikawa S, Schwartz JE et al. Ambulatory blood pressure is a better marker than clinic blood pressure in predicting cardiovascular events in patients with/without type 2 diabetes. Am J Hypertens 2008;21(4):443-50.

105. Dolan E, Stanton A, Thijs L, Hinedi K, Atkins N, McClory S et al. Superiority of ambulatory over clinic blood pressure measurements in predicting mortality: the Dublin outcome study. Hypertension 2005;46(1):156-61.

106. Conen D, Bamberg F. Noninvasive 24-h ambulatory blood pressure and cardiovascular disease: a systematic review and meta-analysis. J Hypertens 2008;26(7):1290-9.

107. Verdecchia P, Schillaci G, Boldrini F, Guerrieri M, Porcellati C. Sex, cardiac hypertrophy and diurnal blood pressure variations in essential hypertension. J Hypertens 1992;10(7):683-92.

108. Zakopoulos N, Stamatelopoulos S, Toumanidis S, Saridakis N, Trika C, Moulopoulos S. $24 \mathrm{~h}$ blood pressure profile affects the left ventricle independently of the pressure level. A study in untreated essential hypertension diagnosed by office blood pressure reading. Am J Hypertens 1997;10(2):168-74.

109. Lekakis JP, Zakopoulos NA, Protogerou AD, Papaioannou TG, Kotsis VT, Pitiriga VCh et al. Arterial stiffness assessed by pulse wave analysis in essential hypertension: relation to24-h blood pressure. Int J Cardiol 2005;102(3):391-5.

110. Salvetti M, Muiesan ML, Rizzoni D, Bettoni G, Monteduro C, Corbellini C et al. Night time blood pressure and cardiovascular structure in a middle-aged general population in northern Italy: the Vobarno Study. J Hum Hypertens 2001;15(12):879-85.

111. Philips RA, Butkevich A, Sheinart KF, Tuhrim S. Dipping is superior to cusums analysis in measurement of the risk of stroke in a case-control study. Am J Hypertens 2001;14(7 Pt 1):649-52. 
112. Kikuya M, Ohkubo T, Asayama K, Metoki H, Obara T, Saito S et al. Ambulatory blood pressure and 10-year risk of cardiovascular and noncardiovascular mortality: the Ohasama study. Hypertension 2005;45(2):240-5.

113. Bouhanick B, Bongard V, Amar J, Bousquel S, Chamontin B. Prognostic value of nocturnal blood pressure and reverse-dipping status on the occurrence of cardiovascular events in hypertensive diabetic patients. Diabetes Metab 2008;34(6 Pt 1):560-7.

114. Verdecchia P. Prognostic value of ambulatory blood pressure: current evidence and clinical implications. Hypertension 2000;35(3):844-51.

115. Koren MJ, Devereux RB, Casale PN, Savage DD, Laragh JH. Relation of left ventricular mass and geometry to morbidity and mortality in uncomplicated essential hypertension. Ann Intern Med 1991;114(5):345-52.

116. Ruilope LM, Schmieder RE. Left ventricular hypertrophy and clinical outcomes in hypertensive patients. Am J Hypertens 2008;21(5):500-8.

117. Verdecchia P, Angeli F, Borgioni C, Gattobigio R, de Simone G, Devereux RB et al. Changes in cardiovascular risk by reduction of left ventricular mass in hypertension: a metaanalysis. Am J Hypertens 2003;16(11 Pt 1):895-9.

118. Zieman SJ, Melenovsky V, Kass DA. Mechanisms, pathophysiology, and therapy of arterial stiffness. Arterioscler Thromb Vasc Biol 2005;25(5):932-43.

119. McEniery CM, Yasmin, Hall IR, Qasem A, Wilkinson IB, Cockcroft JR; ACCT Investigators. Normal vascular aging: differential effects on wave reflection and aortic pulse wave velocity: the Anglo-Cardiff Collaborative Trial (ACCT). J Am Coll Cardiol 2005;46(9):1753-60.

120. Nickenig G, Röling J, Strehlow K, Schnabel P, Böhm M. Insulin induces upregulation of vascular AT1 receptor gene expression by posttranscriptional mechanisms. Circulation 1998;98(22):2453-60.

121. Ikonomidis I, Makavos G, Lekakis J. Arterial stiffness and coronary artery disease. Curr Opin Cardiol 2015;30(4):422-31.

122. Ben-Shlomo Y, Spears M, Boustred C, May M, Anderson SG, Benjamin EJ. Aortic pulse wave velocity improves cardiovascular event prediction: an individual participant metaanalysis of prospective observational data from 17,635 subjects. J Am Coll Cardiol 2014;63(7):636-46.

123. Laurent S, Boutouyrie P, Asmar R, Gautier I, Laloux B, Guize L, Ducimetiere P, Benetos A. Aortic stiffness is an independent predictor of all-cause and cardiovascular mortality in hypertensive patients. Hypertension 2001;37(5):1236-41. 
124. Boutouyrie P, Tropeano AI, Asmar R, Gautier I, Benetos A, Lacolley P, Laurent S. Aortic stiffness is an independent predictor of primary coconary events in hypertensive patients: a longitudinal study. Hypertension 2002;39(1):10-5.

125. Laurent S, Katsahian S, Fassot C, Tropeano AI, Gautier I, Laloux B, Boutouyrie P. Aortic stiffness is an independent predictor of fatal stroke in essential hypertension. Stroke 2003;34(5):1203-6.

126. Guerin AP, Blacher J, Pannier B, Marchais SJ, Safar ME, London GM. Inpact of aortic stiffness attenuation on survival of patients in end-stage renal failure. Circulation 2001;103(7):987-92.

127. Cruickshank K, Riste L, Anderson SG, Wright JS, Dunn G, Gosling RG. Aortic pulsewave velocity and its relationship to mortality in diabetes and glucose intolerance: an integrated index of vascular function? Circulation 2002;106(16):2085-90.

128. Mansour AS, Yannoutsos A, Majahalme N, Agnoletti D, Safar ME, Ouerdane S, Blacher J. Aortic stiffness and cardiovascular risk in type diabetes. J Hypertens 2013;31(8):1584-92.

129. Meaume S, Benetos A, Henry OF, Rudnichi A, Safar ME. Aortic pulse wave velocity predicts cardiovascular mortality in subjects $>70$ years of age. Arterioscler Thromb Vasc Biol 2001;21(12):2046-50.

130. Sutton-Tyrrell K, Najjar SS, Boudreau RM, Venkitachalam L, Kupelian V, Simonsick EM et al. Elevated aortic pulse wave velocity, a marker of arterial stiffness, predicts cardiovascular events in well-functioning older adults. Circulation 2005;111(25):3384-90.

131. Willum-Hansen T, Staessen JA, Torp-Pedersen C, Rasmussen S, Thijs L, Ibsen H, Jeppesen J. Prognostic value of aortic pulse wave velocity as index of arterial stiffness in the general population. Circulation 2006;113(5):664-70.

132. Norman PE, Powell JT. Vitamin D and cardiovascular disease. Circ Res 2014;114(2):379-93.

133. Autier P, Boniol M, Pizot C, Mullie P. Vitamin D status and ill health: a systematic review. Lancet Diabetes Endocrinol 2014;2(1):76-89.

134. Pourshahidi LK. Vitamin D and obesity: current perspectives and future directions. Proc Nutr Soc 2015;74(2):115-24.

135. Forouhi NG, Luan J, Cooper A, Boucher BJ, Wareham NJ. Baseline serum 25-hydroxy vitamin $d$ is predictive of future glycemic status and insulin resistance: the Medical Research Council Ely Prospective Study 1990-2000. Diabetes 2008;57(10):2619-25.

136. Knekt P, Laaksonen M, Mattila C, Härkänen T, Marniemi J, Heliövaara M et al. Serum vitamin D and subsequent occurrence of type 2 diabetes. Epidemiology 2008;19(5):666-71. 
137. Afzal S, Bojesen SE, Nordestgaard BG. Low 25-hydroxyvitamin D and risk of type 2 diabetes: a prospective cohort study and metaanalysis. Clin Chem 2013;59(2):381-91.

138. Schöttker B, Herder C, Rothenbacher D, Perna L, Müller H, Brenner H. Serum 25hydroxyvitamin D levels and incident diabetes mellitus type 2: a competing risk analysis in a large population-based cohort of older adults. Eur J Epidemiol 2013;28(3):267-75.

139. Grimnes G, Emaus N, Joakimsen RM, Figenschau Y, Jenssen T, Njølstad I, Schirmer H, Jorde R. Baseline serum 25-hydroxyvitamin D concentrations in the Troms $\varnothing$ Study 1994-95 and the risk of developing type 2 diabetes mellitus during 11 years of follow-up. Diabet Med 2010;27(10):1107-15.

140. Song Y, Wang L, Pittas AG, Del Gobbo LC, Zhang C, Manson JE, Hu FB. Blood 25hydroxy vitamin $\mathrm{D}$ levels and incident type 2 diabetes: a meta-analysis of prospective studies. Diabetes Care 2013;36(5):1422-8.

141. Saliba W, Barnett O, Rennert HS, Rennert G. The risk of all-cause mortality is inversely related to serum 25(OH)D levels. J Clin Endocrinol Metab 2012;97(8):2792-8.

142. Kramer H, Sempos C, Cao G, Luke A, Shoham D, Cooper R, Durazo-Arvizu R. Mortality rates across 25 -hydroxyvitamin $\mathrm{D}(25[\mathrm{OH}])$ levels among adults with and without estimated glomerular filtration rate $<60 \mathrm{ml} / \mathrm{min} / 1.73 \mathrm{~m} 2$ : the third national health and nutrition examination survey. PLoS One 2012;7(10):e47458.

143. Zhou C, Lu F, Cao K, Xu D, Goltzman D, Miao D. Calcium-independent and 1,25( $\mathrm{OH}) 2 \mathrm{D} 3$-dependent regulation of the renin-angiotensin system in1alpha-hydroylase knockout mice. Kidney Int 2008;74(2):170-9.

144. Guillot X, Semerano L, Saidenberg-Kermanac'h N, Falgarone G, Boissier MC. Vitamin D and inflammation. Joint Bone Spine 2010;77(6):552-7.

145. Shab-Bidar S, Neyestani TR, Djazayery A, Eshraghian MR, Houshiarrad A, Kalayi A et al. Improvement of vitamin D status resulted in amelioration of systemic inflammation in the subjects with type 2 diabetes. Diabetes Metab Res Rev 2012;28(5):424-30.

146. Hermann M, Sullivan DR, Veillard AS, McCorquodale T, Straub IR, Scott R et al. Serum 25-hydroxyvitamin D: a predictor of macrovascular and microvascular complications in patients with type 2 diabetes. Diabetes Care 2015;38(3):521-8.

147. Durup D, Jørgensen HL, Christensen J, Schwarz P, Heegaard AM, Lind B. A reverse Jshaped association of all-cause mortality with serum 25-hydroxyvitamin D in general practice: the CopD study. J Clin Endocrinol Metab 2012;97(8):2644-52.

148. Sempos CT, Durazo-Arvizu RA, Dawson-Hughes B, Yetley EA, Looker AC, Schleicher $\mathrm{RL}$ et al. Is there a reverse $\mathrm{J}$-shaped association between 25 -hydroxyvitamin $\mathrm{D}$ and all-cause 
mortality? Results from the U.S. nationally representative NHANES. J Clin Endocrinol Metab 2013;98(7):3001-9.

149. Hagström E, Hellman P, Larsson TE, Ingelsson E, Berglund L, Sundström J et al. Plasma parathyroid hormone and the risk of cardiovascular mortality in the community. Circulation 2009;119(21):2765-71.

150. Hagström E, Ingelsson E, Sundström J, Hellman P, Larsson TE, Berglund L et al. Plasma parathyroid hormone and risk of congestive heart failure in the community. Eur J Heart Fail 2010;12(11):1186-92.

151. Natoli JL, Boer R, Nathanson BH, Miller RM, Chiroli S, Goodman WG et al. Is there an association between elevated or low serum levels of phosphorus, parathyroid hormone, and calcium and mortality in patients with end stage renal disease? A meta-analysis. BMC Nephrol 2013;14:88.

152. Joergensen C, Gall MA, Schmedes A, Tarnow L, Parving HH, Rossing P. Vitamin D levels and mortality in type 2 diabetes. Diabetes Care 2010;33(10):2238-43.

153. Joergensen C, Hovind P, Schmedes A, Parving HH, Rossing P. Vitamin D levels, microvascular complications, and mortality in type 1 diabetes. Diabetes Care 2010;34(5):1081-5.

154. Wu SH, Ho SC, Zhong L. Effets of vitamin D supplementation on blood pressure. South Med J 2010;103(8):729-37.

155. Forman JP, Scott JB, Ng K, Drake BF, Suarez EG, Hayden DL et al. Effect of vitamin D supplementation on blood pressure in blacks. Hypertension 2013;61(4):779-85.

156. Gepner AD, Ramamurthy R, Krueger DC, Korcarz CE, Binkley N, Stein JH. A prospective randomized controlled trial of the effects of vitamin D supplementation on cardiovascular disease risk. PLoS One 2012;7(5):e36617.

157. Wood AD, Secombes KR, Thies F, Aucott L, Black AJ, Mavroeidi A et al. Vitamin D3 supplementation has no effect on conventional cardiovascular risk factors: a parallel-group, double-blind, placebo-controlled RCT. J Clin Endocrinol Metab 2012;97(10):3557-68.

158. Bolland MJ, Grey A, Gamble GD, Reid IR. The effect of vitamin D supplementation on skeletal, vascular, or cancer outcomes: a trial sequential meta-analysis. Lancet Diabetes Endocrinol 2014;2(4):307-20.

159. Flodin M, Jonsson AS, Hansson LO, Danielsson LA, Larsson A. Evaluation of Gentian cystatin $\mathrm{C}$ reagent on Abbott Ci8200 and calculation of glomerular filtration rate expressed in $\mathrm{mL} / \mathrm{min} / 1.73 \mathrm{~m}(2)$ from the cystatin C values in $\mathrm{mg} / \mathrm{L}$. Scand J Clin Lab Invest 2007;(67)5:560-7. 
160. Devereux RB, Reichek N. Echocardiographic determination of left ventricular mass in man. Anatomic validation of the method. Circulation 1977;(55)4:613-8.

161. National Survey of Public Health, Swedish National Institute for Public Health.

Available at http://www.fhi.se/Documents/English/Highlights/survey-English-2007.pdf (English version) last accessed 19 March 2012.

162. Tudor-Locke C, Sisson SB, Lee SM, Craig CL, Plotnikoff RC, Bauman A. Evaluation of quality of commercial pedometers. Can J Public Health 2006;97 Suppl 1:S10-5, S10-6. 



\section{Papers}

The articles associated with this thesis have been removed for copyright reasons. For more details about these see:

http://urn.kb.se/resolve?urn=urn:nbn:se:liu:diva- 125911 